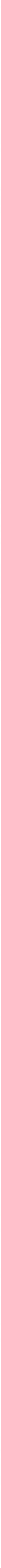




\section{Hemcinobartr verunt:}

\section{Микеланджело}

\section{Буонарроти}

«...Он никогда не подчинялся никаким законам, ни старыли, ни новым, как художник, обладавиий гением, способным всегда находить нечто новое и невиданное, но нисколько от этого не менее прекрасное» - так описывал Джорджо Вазари (1511-1574 гг.) творческую деятельность своего старшего коллеги и друга Микеланджело Буонарроти, который был единственным современником автора «Жизнеописаний наиболее знаменитых живописцев, ваятелей и зодчих» (1550 г.) Как утверждал Асканио Кондиви (1525-1574 гг.), ученик Микеланджело и автор еще одной его биографии, вышедшей в свет в 1553 году и во многих деталях имеющей сходство с биографией, написанной Вазари, художник обладал столь удивительной памятью, что, написав тысячи фигур, «никогда не делал одну похожею на другую или повторяющею позу другой» и даже слышал от него, что он «не проводит не одной линии, прежде чем не припомнить и не убедиться в том, что никогда им не сделано подобной и уничтожает ту, в которой не находит новизны». «Его воображение так велико, - писал Кондиви, - что он никогда не довольствуется своими работами и постоянно критикует их, говоря, что ему не удалось достигнуть того, что им первоначально было задумано».

\section{Чagrb I}

Дмитрий Боровков, историк-архивист

\section{Кондиви характеризовал Микеланджело как роб-} кого человека, которого несправедливые обвинения в его адрес могли сделать «смелее самых смелых», поэтому его можно назвать «бунтарем от искусства» - особенно, если иметь в виду не только его творческие методы, но и далеко не простые отношения с высокими покровителями.

П. Предполагаемый портрет Микеланджело в образе Гераклита Эфесского.

Худ. Рафаэль Санти. Фрагмент фрески «Афинская школа», Станца делла Сеньятура. $1509-1511$ гг. Ватиканский дворец, Рим. 


\section{Микеланджело в Капрезе}

Наряду с палаццо Клузини (Palazzo Clusini) и бывшим зданием Верховного суда (Corte Alta), палаццо Подеста (Palazzo del Podesta) - т.е. палаццо, где жил глава местной администрации (podesta), - сейчас входит в комплекс зданий местного Микеланджеловского музея (Museo Michelangiolesco). Все три постройки представляют собой остатки средневековой крепости Kaпрезе (La Rocca di Caprese), когда-то принадлежавшей графам Гвиди. Видимо, уже в XIII веке у подножия замка образовалось небольшое селение, превратившееся к XIV веку в город. В 1324 году крепость осадила армия под предводительством Пьера Сакконе Тарлати, родного брата Гвидо Тарлати, епископа Ареццо. Через год осады крепость пала, и земли попали под власть епископства Ареццо. В 1384 году Капрезе оказался под властью Флоренции, и в городе была введена должность подеста.

Corte Alta - самое старое здание на месте старой крепости Капрезе, оно датируется XIV веком. В начале XV века было построено палаццо Подеста, а во второй половине XV века - палаццо Клузини. До XIX века палаццо Подеста было местом постоянного проживания главы города Капрезе. Его семья занимала комнаты на втором этаже, тогда как на первом размещалась городская почта. В палаццо Клузини жил городской врач, фамилия последнего из них сохранилась в названии дворца.

В 1474-1475 годах главой администрации города был Лодовико ди Леонардо Буонарроти Симони, в семье которого 6 марта 1475 года родился будущий гений Высокого Возрождения. В 1875 году в архиве Дома Буонарроти (Casa Buonarroti) во Флоренции был найден автограф самого Лодовико Буонарроти с записью о рождении сына и его последующем крещении в местной церкви Св.Иоанна Крестителя (San Giovanni Battista): «Сегодня, 6 марта... у меня родился мальчик, я назвал его Микеланджело, и он родился в понедельник утром между 4 и 6 часами, и родился он тогда, когда я был подеста в Капрезе... Я крестил его 8 числа того же месяца в церкви Сан Джованни в Капрезе». Принято считать, что Микеланджело родился в одной из комнат на втором этаже палаццо Подеста. В том же, 1875 году (отмеченном празднованием 400-летней годовщины со дня рождения гения), стали восстанавливать сохранившиеся здания крепости. Небольшая экспозиция, развернутая в отреставрированном палаццо Подеста, стала ядром будущего Микеланджеловского музея. 9 февраля 1913 года королевским указом к названию городка Капрезе было прибавлено имя Микеланджело. Только к 1964 году были закончены реставрационные работы в Corte Alta, a палаццо Клузини открылся для посетителей буквально несколько лет назад (здесь разместились кассы музея, библиотека и выставочные залы). Официальное открытие музея состоялось в 1864 году, когда отмечали 400-летнюю годовщину со дня смерти Микеланджело.

* Rocca (итал.) - крепость на горе, цитадель.

Кондиви характеризовал Микеланджело как робкого человека, которого несправедливые обвинения в его адрес могли сделать «смелее самых смельх», поэтому его можно назвать «бунтарем от искусства» особенно, если иметь в виду не только его творческие методы, но и далеко не простые отношения с высокими покровителями, хотя, не следует забывать и о том, что первые биографы мастера, сознательно занимавшиеся мифотворчеством, в интерпретации многих событий тенденциозны, как это выясняется после сравнения их рассказов с некоторыми документами той эпохи.

Итальянское Возрождение дало миру немало прославленных мастеров, но исполинская мощь творческого гения Микеланджело Буонарроти выделяет его даже среди величайших художников этой эпохи. Хотя Леонардо и Рафаэль были почти столь же разносторонними мастерами, именно ему было суждено создать во всех видах искусства произведения наиболее грандиозные по своим масштабам, с исключите-

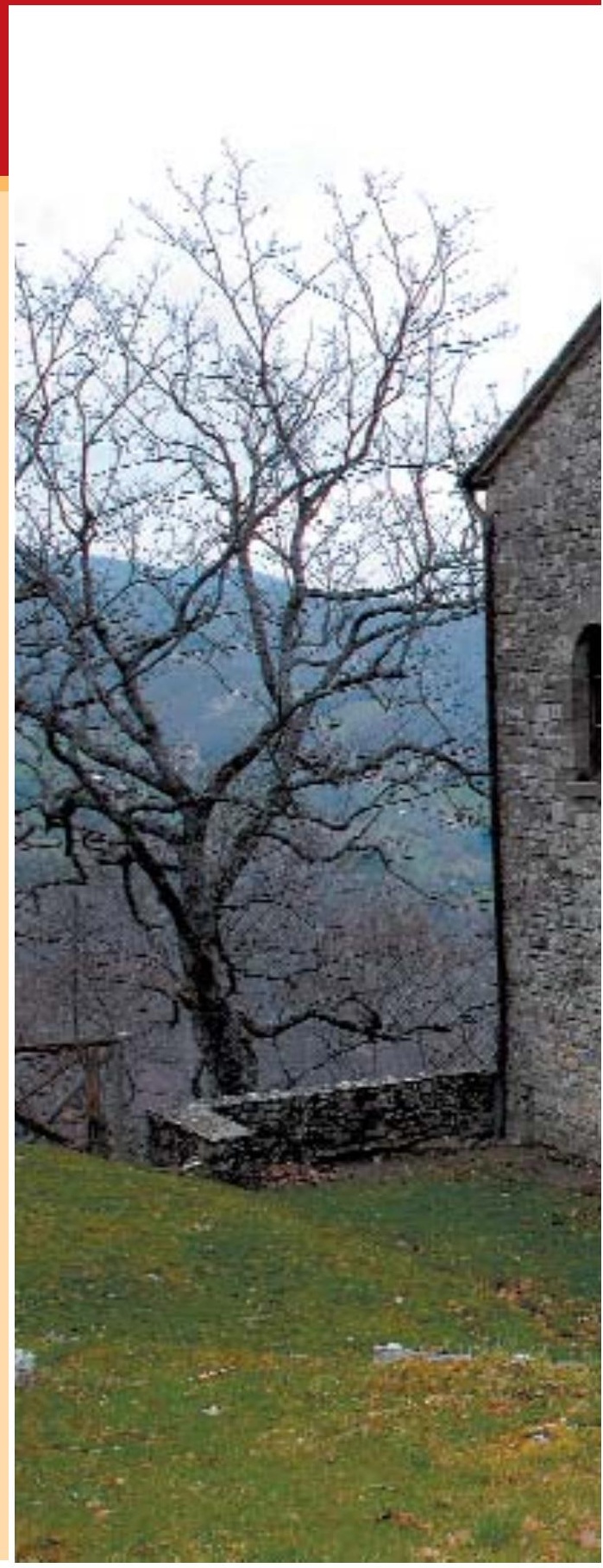

льной силой и яркостью выразившие содержание эпохи Ренессанса.

Прирожденный скульптор, Микеланджело начал свою художественную деятельность с живописи, а закончил ее в качестве архитектора. "Переход Микеланджело от живописи к скульптуре не бьл само собой разумеюшиимя, как и вся концепция «ниверсального гения, отмечают немецкие искусствоведы Габриэле Бартц и Эберхард Кёниг. Хотя до него во Флорениии как живописеи, скульптор и литейиик по бронзе уже работал Андреа Ве- 


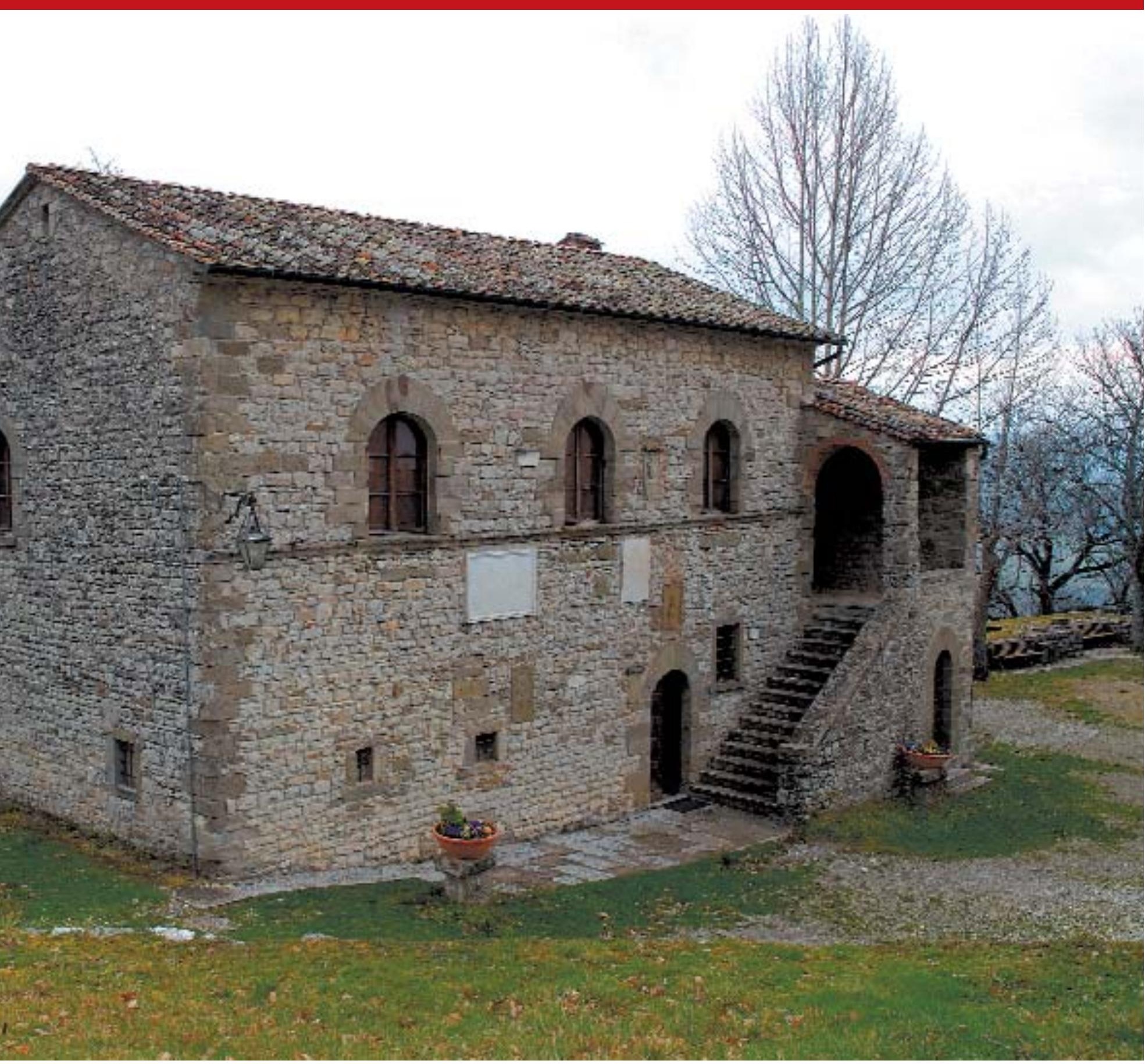

роккъо (1436-1488 г2.) Тем не менее, от нормы, которая определяла деловую деятельность художников того времени, такой стиль работы был весыма далек», поэтому «в истории художественного образования он сыграл совериенно новую роль" и принадлежал к «певому подрастаюмему поколению художников, которые приобретали уже более универсальное образование». Здесь необходимо заметить, что понятие «нормы» к гениям вообще не применимо, а Микеланджело как раз и являет собой редкий пример не
Хотя Леонардо и Рафаэль были почти столь же разносторонними мастерами, именно Микеланджело Буонарроти было суждено создать во всех видах искусства произведения наиболее грандиозные по своим масштабам, с исключительной силой и яркостью выразившие содержание эпохи Ренессанса. 


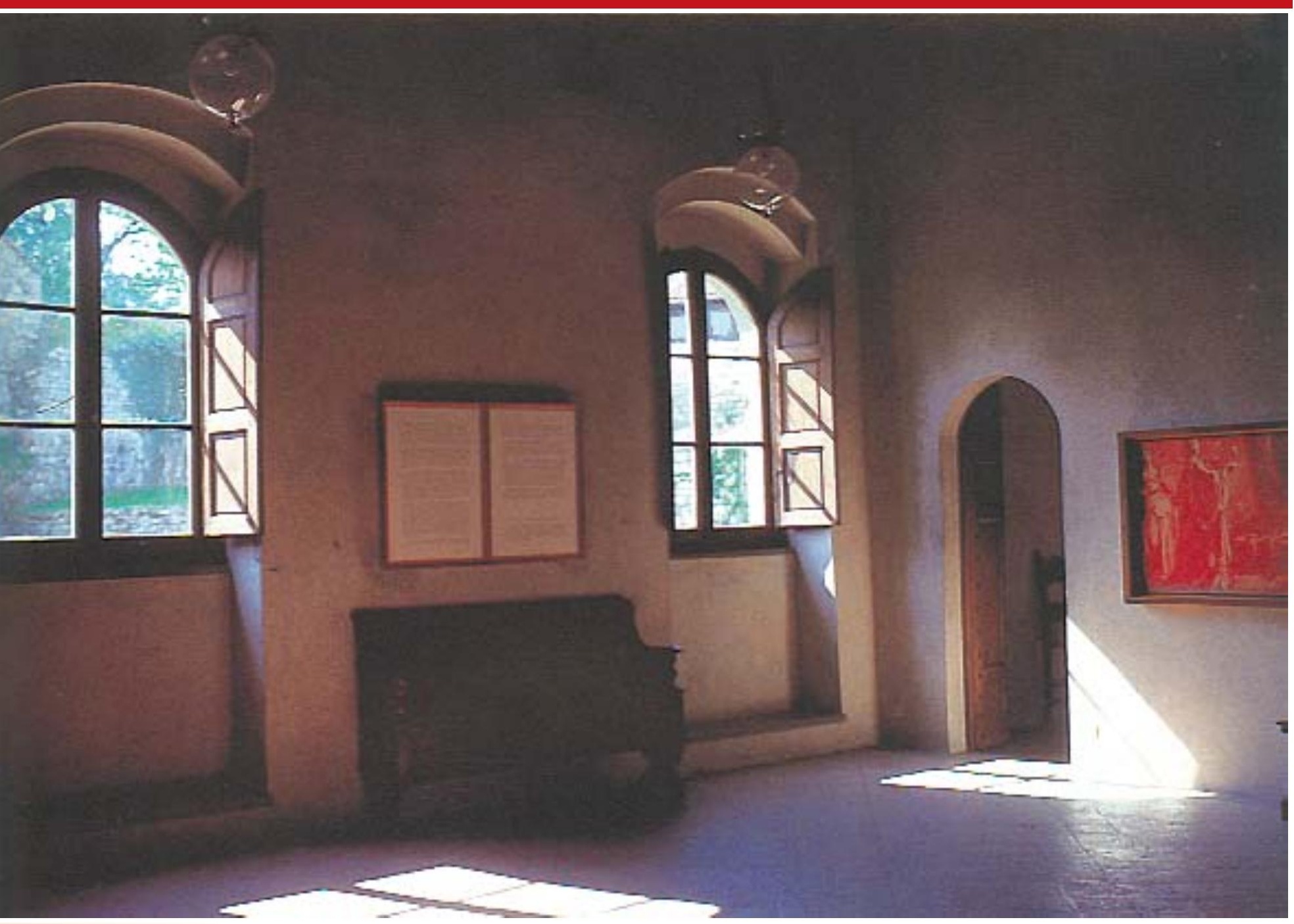

просто большого таланта, а подлинной гениальности. Что же касается концепции «ниверсального гения", то в области искусства она применима, по большому счету, только к двум Титанам Возрождения - Леонардо да Винчи и Микеланджело Буонарроти.
Искусство Микеланджело знаменует не только кульминацию эпохи Возрождения, но и ее завершение Долгий, почти семидесятипятилетний творческий путь мастера охватил огромный исторический период, полный бурных потрясений. С этим связаны более сложная, чем у его
Часто говорят, что Микеланджело «стал судьбой итальянского искусства». В этом утверждении содержится не только глубокий философский смысл, но и подразумеваются вполне конкретные события. Как справедливо заметил Макс Дворжак: «С момента создания «Страшного суда» все итальянского искусство проникается микеланджеловским духом» современников, идейная эволюция Микеланджело, многоэтапность его искусства и исключительное многообразие его художественных решений.

Часто говорят, что Микеланджело «стал судъбой итальянского искусства». В этом утверждении содержится не только глубокий философский смысл, но и подразумеваются вполне конкретные события. Как справедливо заметил Макс Дворжак: "С момента создания «Страшного суда» все итальянского искусство проникается микеланджеловским духом, и это отражается не только на отдельных формах, но и на всем мышлении, усваивающем как новое представление об идеально вневременнол, пространственно всеприемлемом начале, так и несльханную доселе духовную патетику. [...] ... если мы хотим исчерпьвающе изобразить воздействие этой фрески, то должны перечислить все произведения, 
Слева:

Холл на втором этажа палаццо Подеста. Полукруглая дверь справо ведет в комнату, где, по преданию, родился Микеланджело.

Справа:

Тритон. Рисунок углем. До 1488 г. Сеттиньяно, Вилла Буонарроти.

Многие исследователи сиитают, ито этот рисунок на стене дола в Сеттиньяно был сделан Микеланджело еще до ученичества в мастерской Гирландайо. Датируется приблизительно.

возникшие в Италии (а частично также и севернее Альп) в период между созданием "Страшного суда" и завериением эпохи барокко».

Одним из ярких художественных течений в европейской культуре XVI века (для Италии это - эпоха Позднего Возрождения) стал «маньеризм», являвший собой драматический протест против изобразительных принципов «классического стиля» флорентийско-римского Высокого Возрождения. По определению Л. М. Баткина, маньеризм - это «реакция внутри Возрождения и предвестие его скорого конща». Появление маньеризма связывают с глубоким кризисом гуманистического ренессансного мировосприятия, поисками новых форм выражения смятенного, иногда иррационального восприятия мира. В основе художественного образа художников-маньеристов лежит положение о главенства воображения, личного творческого начала мастера. Внешним выражением этой «внутренней идеш» становится «прекрасная манера» как сумма определенных стилистических приемов. Источниками этих самых новых приемов (сложных формул движения, змеевидного ритма поз, произвольная вытянутость пропорций) стали поздние работы Рафаэля и Микеланджело.

Отчасти, Микеланджело можно назвать неким связующим звеном между искусством Высокого Возрождения и маньеризмом. Его творческий путь, по словам Е.И. Ротенберга,

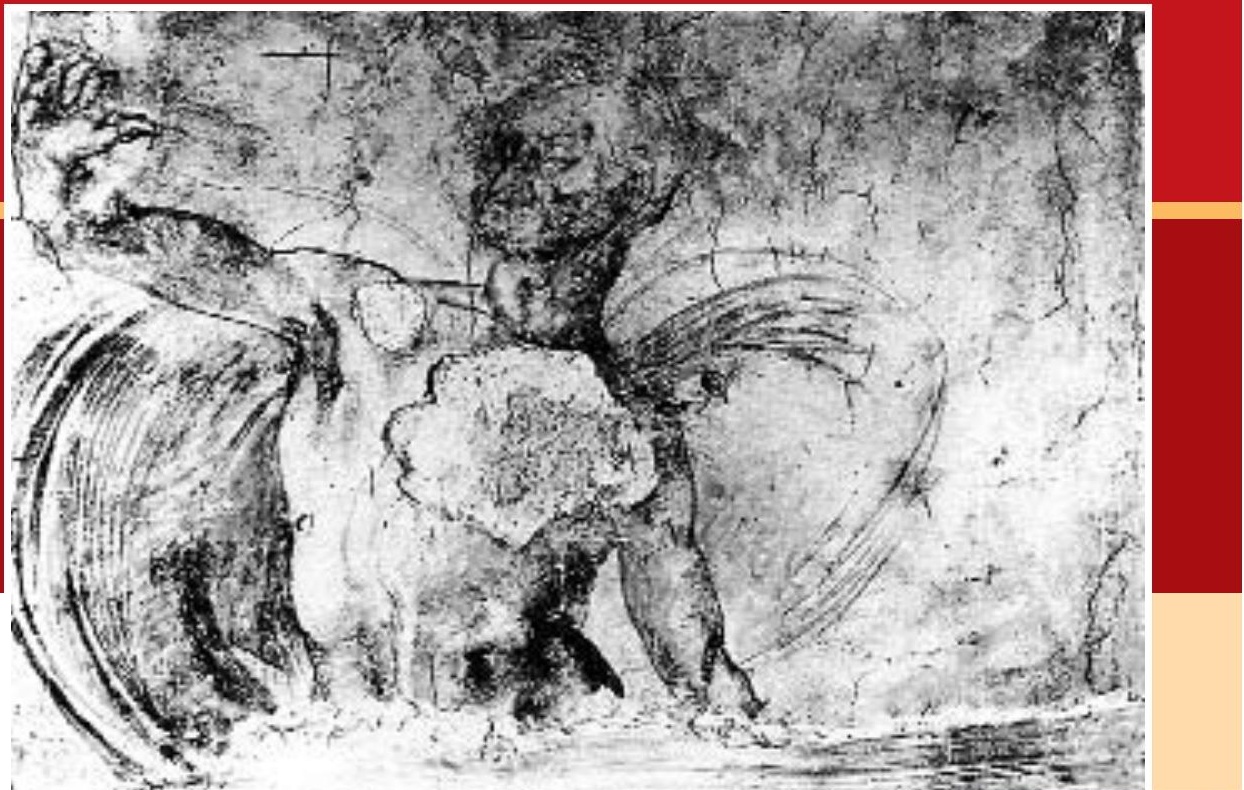

«это наиболее яркое выражение магистральной линии в искусстве Итальянского возрождения. Данный факт объясняется не только маситабом дарования Микеланджело, но и особенностями его художественного мировосприятия и творческого метода. Человек был в центре внимания у всех мастеров итальянского Возрождения, но именно в искусстве Микеланджело ренессансный гуманистический идеал находит свое высшее, предельно яркое выражение, ибо Микеланджело выделяет в этом идеале его основу, сердиевину, самое ценное качество - активность, действенность человека, его способность $\kappa$ герочческому подвигу. [...] В этом отношении антропоцентризм Ренессанса достигает у Микеланджело не только своей вериины, но и своей крайности. Художника интересует только человек; его арена действия, реальное жизненное окружение - все это для Микеланджело почти не существует. Так определяется специфическая особенность творческого дарования мастера: из всех видов изобразительного искусства именно скульптура, открываюшая особенно благоприятные возможности для обобщенно-герочческого воплощения человеческого образа и одновременно освобождаюоиая художника от всего, что находится вне человека, привлекла наибольшее внимание Микеланджело. Сам он неоднократно называл себя только скульптором, и это справедливо не потому лишь, что среди других видов изобразительного искусства он отдавал предпочтение скульптуре; характер его мировосприятия, безраздельное господство человека в его искусстве - все это приводило $\kappa$ тому, что в своих живописных и графических произведениях он во многом оставался скульптором. Именно эта особенность образного мышиления Микеланджело предопределила повыменную пластическую силу образов в его фресках, картинах и рисунках, она сообиила свой отпечаток архитектурным созданиям мастера».

\section{ОТ УЧЕНИКА К МАСТЕРУ (1475-1505 гг.)}

Микеланджело, или Микельаньоло (Michelagniolo), как он сам себя именовал, родился в селении Капрезе (сейчас это маленький тосканский городок, который называется Капрезе-Микеланджело) 6 марта 1475 года в семье флорентийского дворянина Лодовико Буонарроти Симони, который в то время исполнял в этой местности функции podestà̀ $^{1}$ и Франчески Ручеллаи -

${ }^{1}$ Подеста (ит. podesta, от лат. pотеstia- власть) - в ряде итальянских городов-коммун ХІІ - начала ХVI вв. - глава исполнительной и судебной власти. В XIV - начале ХVI вв. подеста выполняли лишь судебные функции. В современном понимании подеста соответствует должности мэра города, но с рядом дополнительных обязанностей, которых нет у нынешних градоначальников. прим.ред 


\section{VITA DT MTCHELACNOLO DVONARKOTL}

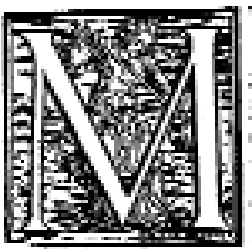

ICHILACNOL Insouanod Pituare Scultore fingulere, habbel'orígin fra cha Concída Crnoflino bile $\boldsymbol{\alpha}$ illuttre frmis glin del renirorio di Roggía, fi per virrui propria , \& antichuri, fi pus hauer fario pes renado col singar Imptríle, Hertioche Besarice forclla d Henrico. Il fu date per trogliesal Conet Bonifacio da Canothasiho ñ Stznor di Mrntutuas , donde pe nacgue la Conceffa Mathilda, donna dí rara gr litrgus larprudenza 8 acligione. Laquale doppo. panotte del tharifo Corthifredo, tenne in Italia olue d Matrous, Lucca, Farmo \&

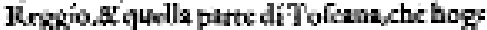
vifichixensil Patrimonio di fan piero: it graendo in vied fattemolte cole degne di memoria,morendo fa fepolta netla Hedia di fan Benedectoo faor di Mantoos/la zqual illa haveua fíbricene os lergemence dortur. Di cal famiglia adu no N Nd. M, CC. L. Vinen do4 rírensie per potefla vi Mifer Sirroule, intrits per fux vartta d' effere farmo Citadítio

A

также дамы благородного происхождения. Согласно преданию, которое разделяли историографы XVI века, род Буонарроти восходил к семейству графов Каноссы, один из членов которого во время противостояния гвельфов и гибеллинов в середине XIII века переселился во Флоренцию и получил флорентийское гражданство. Позднее было доказано, что это легенда, хотя представители рода Буонарроти действительно появляются на исторической сцене в ХІІІ столетии. Сам Микеланджело в одном из писем к своему племяннику Леонардо в декабре 1546 года упоминает, что в одной из рукописных книг со старинными флорентийскими хро-
Первая страница из «Жизнеописания Микеланьоло Буонарроти»

(Vita di Michelagnolo Buonarroti, 1553) Асканио Кондиви.
Флоренция. $\Rightarrow$

Фрагмент карты 1500 г.

Колыбелью итальянского искусства эпохи Высокого Возрождения, местом его возникновения и сложения его основ была Флоренция, сыгравшая до этого решающую роль в становлении искусства Ренессанса на его ранних этапах. Во Флоренции начали свой путь или сформировались как художники Леонардо, Микеланджело и Рафаэль. Однако на рубеже XV и XVI веков в качестве другого ведущего центра страны выдвигается Рим.

никами он нашел жившего лет двести тому назад (то есть, в половине XIV века) «некоего Буонаррото Симони, избиравшегося несколько раз в Синьорию, далее некоего Симоне Буонарроти, далее некоего Микеле ди Буонаррото Симони, далее некоего Франческо Буонарроти».

Ранние детские годы, по словам Вазари, Микеланджело провел недалеко от Флоренции в местечке Сеттиньяно, где у его отца был «небольшой земельный участок, полученный по наследству”, а точнее небольшая ферма 2 . По удивительному совпадению, в этом скалистом местечке издавно жили скульпторы и каменотесы, поскольку здесь были залежи маккиньо - серого камня вулканических пород, использовавшегося архитекторами и скульпторами эпохи Возрождения. Кормилицей Микеланджело стала «жена одного каменотеса». Не случайно, уже в зрелые годы в одном из разговоров с Вазари великий мастер, шутя, признавался: «джорджо, все хорошее в моем таланте получено мною от мягкого климата вашей аретинской земли, а из молока моей кормилицы извлек я резец, и молот, которыми создаю свои статуи.

Интерес к рисованию Микеланджело проявил рано - гуманист Бенедетто Варки писал, что он «охотнее проводил время с теми, кто рисует, нежели с теми, кто учится». Здесь имеется в виду его дружба с Франческо Граначчи ${ }^{3}$, который уже числился учеником известного флорентийского живописца Доменико Гирландайо, в то время как юный Микеланджело по настоянию отца посещал латинскую школу Франческо да Урбино. По словам Кондиви, Микеланджело «с детских лет был очень трудолюбив и к природным дарованиям присоединил ученость, которую приобрел не от других талантливых людей, а из изучения самой природы, настоящего источника всех знаници. На стене первого этажа дома Буонарроти в Сеттиньяно сохранился рисунок, предположительно «Тритона», выполненный

Автопортрет Джорджо Вазари. Гравюра из «Жизнеописаний наиболее знаменитых живописцев, ваятелей и зодчих» (1568г.)

Сейчас этот небольшой сельский дом известен как «вилла Микеланджело» (Villa Michelangelo). - Прим.ред.

${ }_{3}^{3}$ дружба с Франческо Граначчи (1469-1543 г2.) продолжилась и позднее. В 1508 г.Микеланджело пригласил его в качестве помощника для росписи Сикстинского потолка Когда в 1529 г. мастер бежал из Флоренции в Венечию, Граначчи следил за сохранностью его имущества. - Прим.ред.

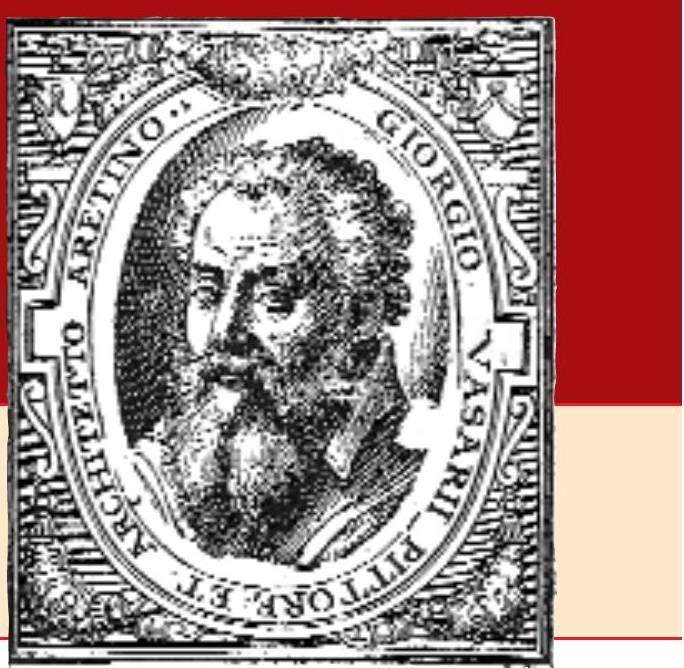




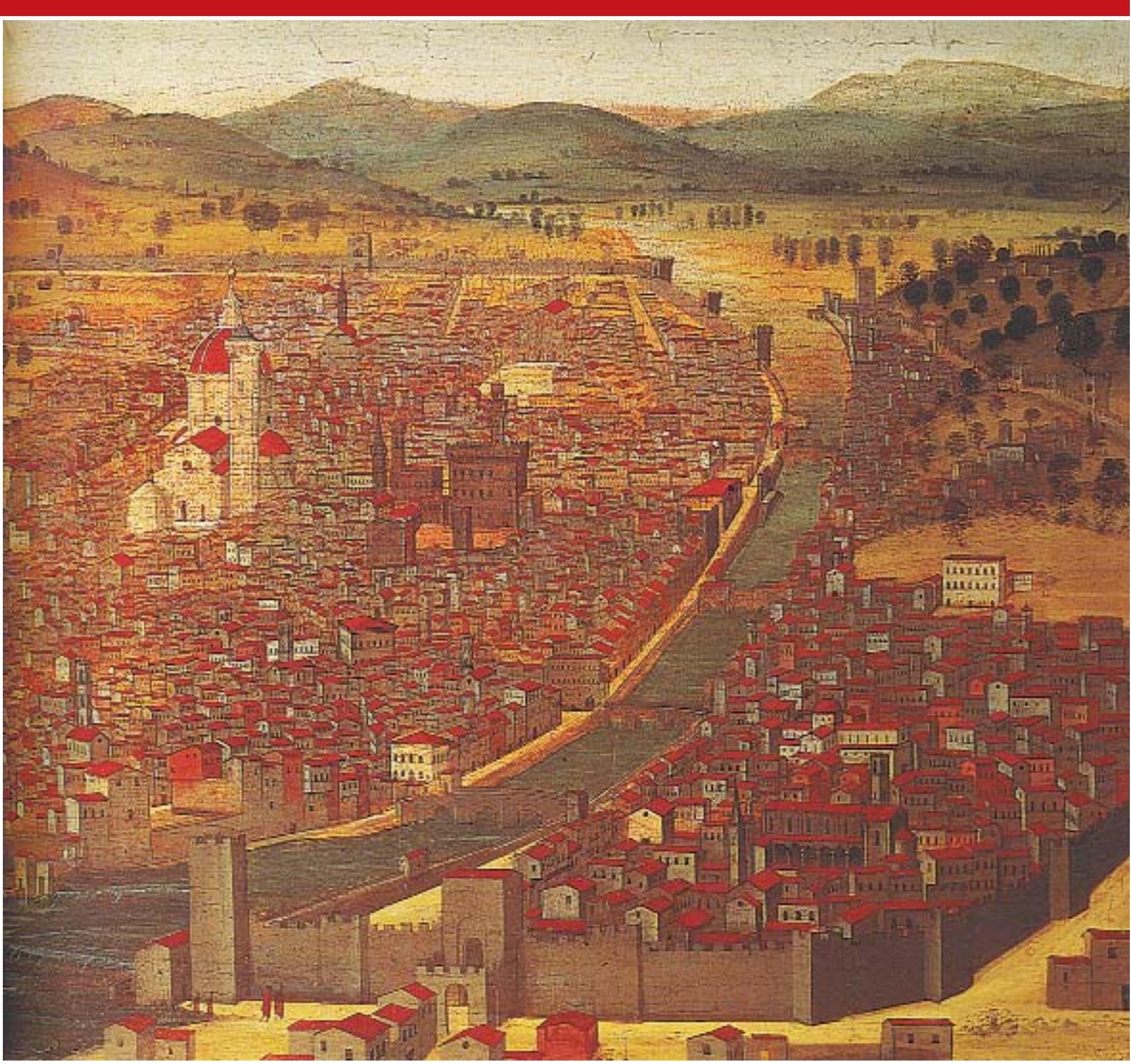

углем поверх штукатурки. Некоторые исследователи считают, что его мог сделать сам Микеланджело еще в юном возрасте.
Однако его увлечение не нашло понимания у родственников - отец и его братья ругали и даже били его, считая занятие искусством делом
Интерес к рисованию Микеланджело проявил рано - гуманист Бенедетто Варки писал, что он «охотнее проводил время с теми, кто рисует, нежели с теми, кто учится». Здесь имеется в виду его дружба с Франческо Граначчи. недостойным для дворянина, ибо художники тогда считались людьми низкого звания. ${ }^{4}$ Однако, в конце концов, Лодовико Буонарроти сдался и в 1488 году, а быть может и несколько раньше, отдал сына в обучение к Гирландайо. По своему обыкновению, Вазари рассказывает

${ }^{4}$ В представлении Лодовико Буонарроти не было никакой «разницы между скульптором и каменотесом». - Прим. ред. 


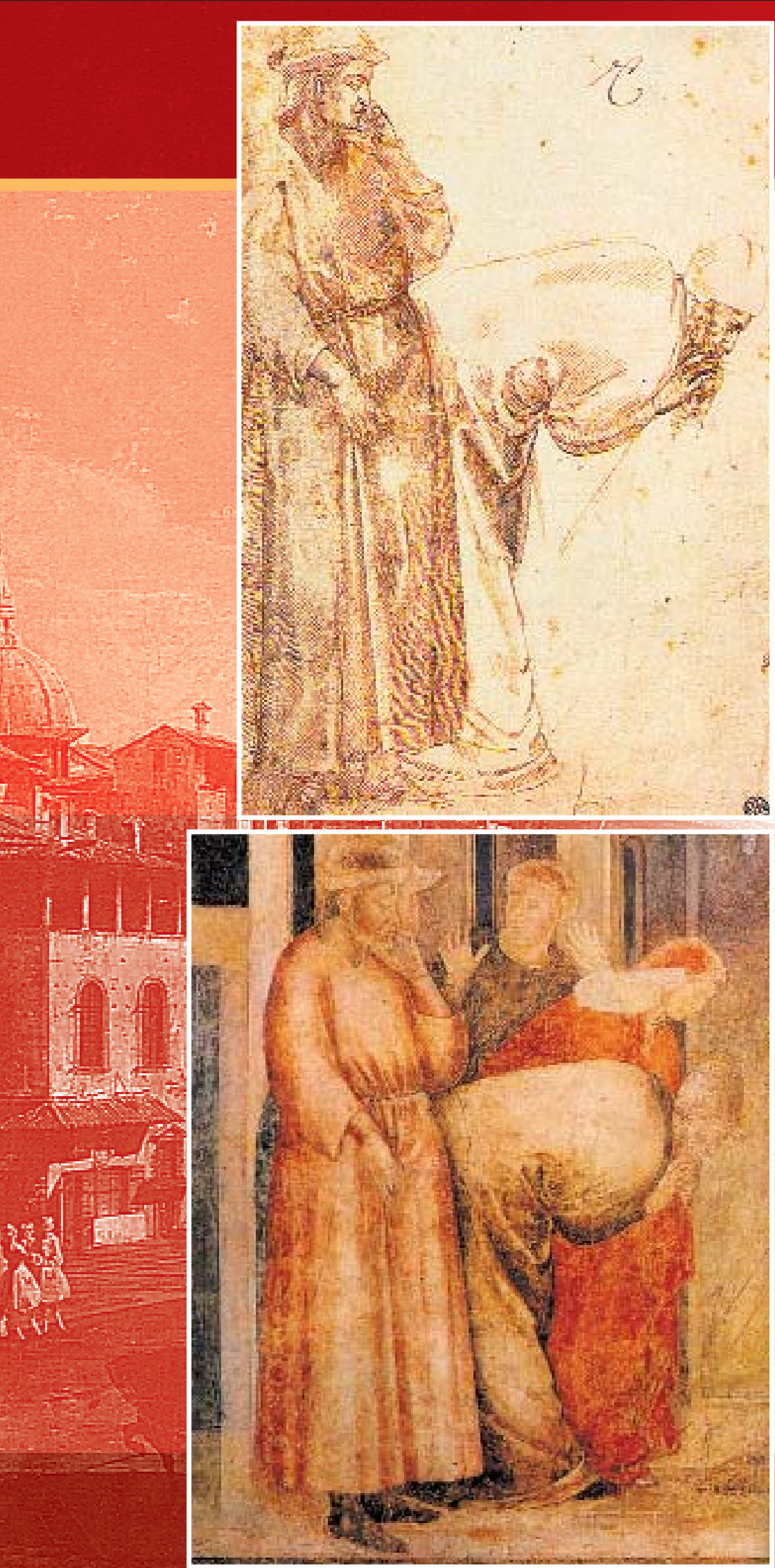

Две фигуры с фрески Джотто «Вознесение Иоанна Евангелиста» в капелле Перуцци церкви Санта Кроче во Флоренции. Рисунок пером Микеланджело Буонарроти. Около 1490 г. Лувр, Париж.

историю, подобную той, какую он приводит в биографии Леонардо да Винчи, и некоторых других живописцев итальянского Возрождения: «случилось так, что когда Доменико работал в большой капелле в Санта Мария Новелла и как-то оттуда вышел, Микеланджело начал рисовать с натуры дощатые подмостья с несколькими столами, заставленными всеми принадлежностями искусства, а также и несколько юношей, там работавиих. Недаром, когда Доменико возвратился и увидел рисунок Микеланджело, он заявил: «ну, этот знает больше моего» - так он был поражен новой манерой и новым способом воспроизведения натуры, которым по приговору неба был одарен этот юноша в возрасте столь нежном, да и в самом деле рисунок был таков, что большего нельзя было бы и пожелать от умения художника, работавиего уже много лет».

Традиционное обучение в мастерской какого-либо художника в те времена состояло из нескольких этапов. Сначала ученики должны были приобрести навыки правильного рисования. Для этого они копировали рисунки известных мастеров, которые в изобилии имелись в каждой мастерской. Следующим этапом было рисование гипсовых моделей и скульптуры, чтобы верно передавать объем и правильно строить ракурс. И только после всего этого ученики допускались к рисованию с натуры. Ко времени ученичества у Гирландайо сохранилось лишь несколько рисунков Микеланджело - копий с фресок Мазаччо и Джотто.

По условиям договора Микеланджело должен был пробыть в мастерской Гирландайо три года, но уже в 1489 году он перешел в художественную школу, которая была открыта Лоренцо Великолепным в так называемых «садах Медичи» у площади СанМарко

Фрагмент фрески «Вознесение Иоанно Евангелиста». Худ. Джотто ди Бондоне.

Капелла Перуцци, церковь Санта Кроче, Флоренция.

В садах Медичи (другое название - Сад Сан-Марко) Лоренио Медичи создал своего рода первую в Европе Академию художеств, где молодые дарования могли изучать произведения знаменитых мастеров и различные художественные техники, заниматься копированием античных древностей из коллекции семьи Медичи. Сады Медичи находились в так называемом «квартале Медичи", в нескольких минутах ходъбы от палацио Медичи и патронируемых ими церквей - Сан-Марко и Сан-Лоренцо, между современными виа Кавур и виа Сан-Галло - Прим.ред. 
Рисующий юноша. Рисунок Мазо Финигуэрра. 1460-е гг.

Галерея Уффици, Флоренция. тольдо ди Джованни, ученика знаменитого Донателло. Кондиви пишет, что Микеланджело сделал так по собственному желанию, но, по словам Вазари, Доменико Гирландайо направил его туда в числе других учеников по просьбе правителя Флоренции для обучения скульптуре.

Согласно рассказу все того же Вазари, уже через несколько дней Микеланджело начал делать копию античной головы фавна и, «руководствуясь собственной фантазией», выдолбил рот фавна таким образом, что были видны не только зубы, но и язык. Когда статую увидел Лоренцо Великолепный, то сказал ему: «Тебе следовало бы только знать, ито у стариков не все зубы бывают иель, сколько-нибудь их всегда не хватает». Микеланджело же показалось, что Лоренцо говорит с ним серьезно, и после его ухода он выломал у статуи один верхний зуб и пробил челюсть так, что казалось, будто зуб выпал.

На самом деле нет ничего удивительного в том, что юный Микеланджело практически сразу же продемонстрировал недюженные способности к ваянию. Уже в ранних его рисунках, копировавших работы мастеров XIV-XV веков, чувствовалась прирожденная рука скульптора: сильными, энергичными линиями он строил форму так, что она казалась высеченной из камня, а фигуры обретали могучий рельеф и внутреннюю силу. Темперамент, творческая фантазия и склонность к героизации - вот те качества, что уже с юных лет отличали художественный почерк Микеланджело Буонарроти. Как справедливо заметил В.Н. Лазарев, его прив-
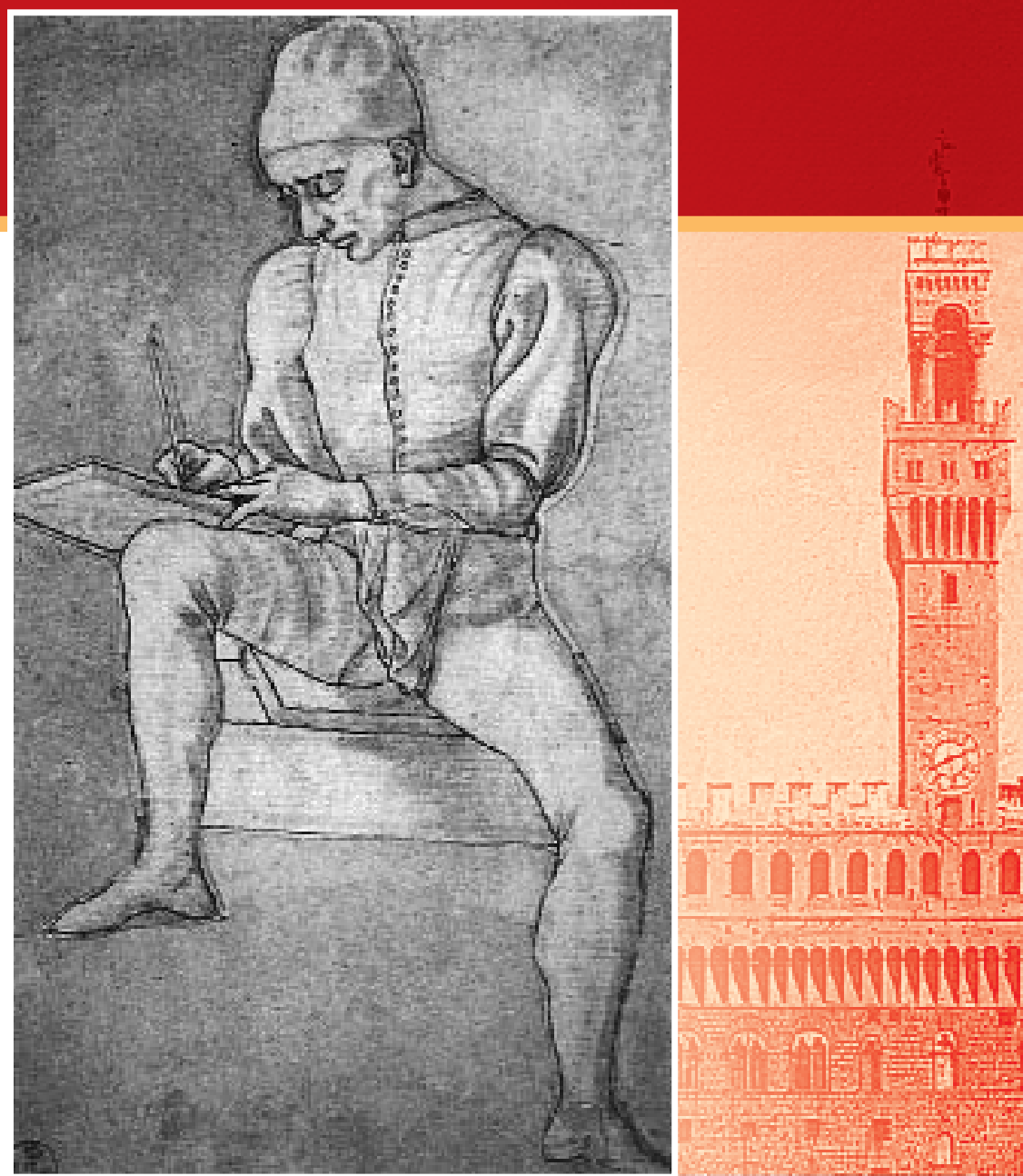

лекало «все по-настоящему значительное и нравственно чистое».

Как рассказывает Вазари, после случая с фавном Лоренцо забрал Микеланджело в свою резиденцию, где тот оставался вплоть до смерти своего покровителя в 1492 году. «все это время, - пишет Вазари, - Микеланджело получал от синъора этого содержание для поддержки отиа в размере пяти дукатов в месяи, и, чтобы доставить ему удовольствие, синъор подарил ему красный плаш, а отиа устроил в таложне». Конди-
Когда статую увидел Лоренцо Великолепный, то сказал ему: «Тебе следовало бы только знать, что у стариков не все зубы бывают целы, скольконибудь их всегда не хватает». Микеланджело же показалось, что Лоренцо говорит с ним серьезно, и после его ухода он выломал у статуи один верхний зуб и пробил челюсть так, что казалось, будто зуб выпал. 

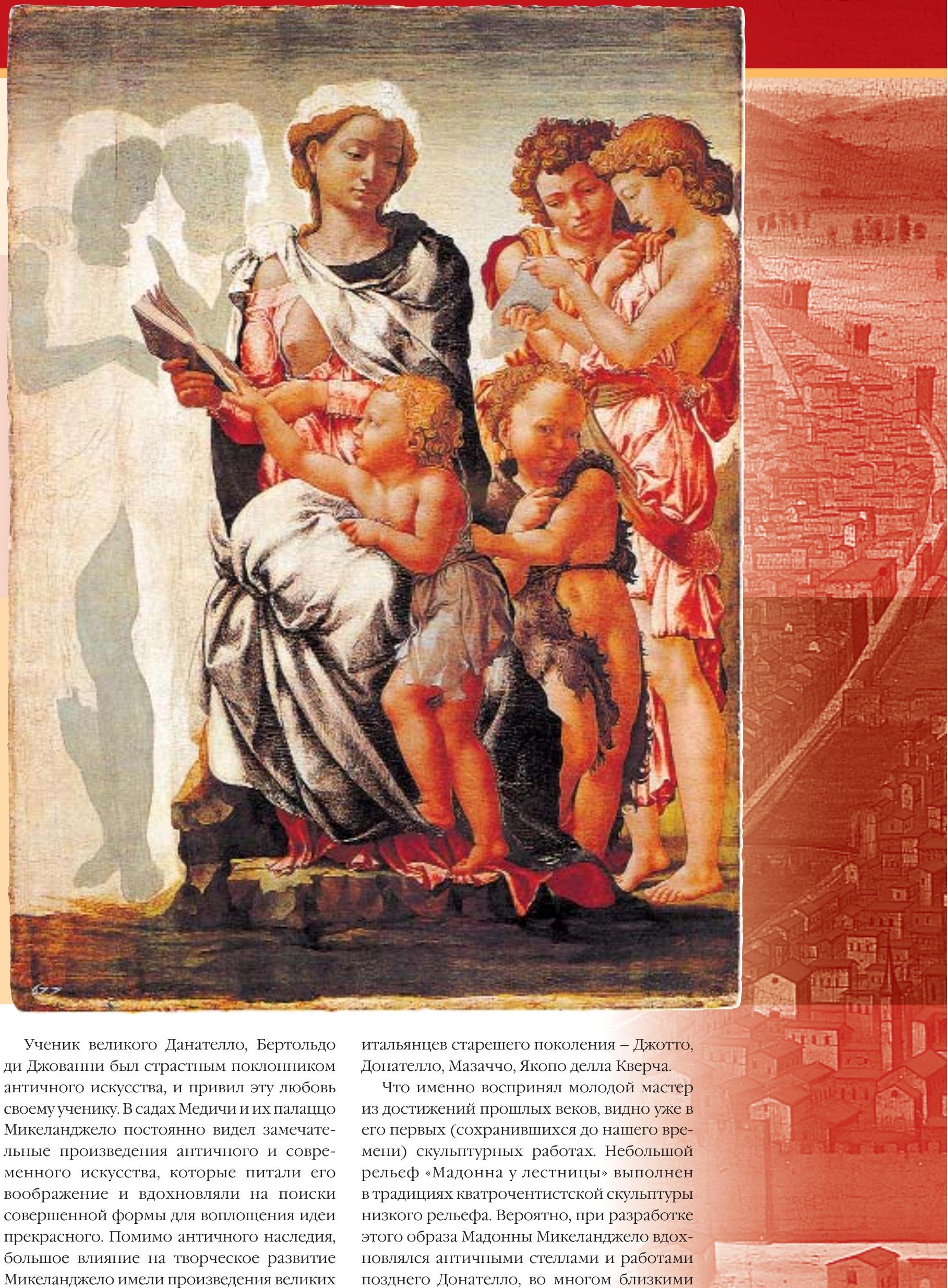

Ученик великого Данателло, Бертольдо ди Джованни был страстным поклонником античного искусства, и привил эту любовь своему ученику. В садах Медичи и их палаццо Микеланджело постоянно видел замечательные произведения античного и современного искусства, которые питали его воображение и вдохновляли на поиски совершенной формы для воплощения идеи прекрасного. Помимо античного наследия, большое влияние на творческое развитие Микеланджело имели произведения великих итальянцев старешего поколения - Джотто, Донателло, Мазаччо, Якопо делла Кверча.

Что именно воспринял молодой мастер из достижений прошлых веков, видно уже в его первых (сохранившихся до нашего времени) скульптурных работах. Небольшой рельеф «Мадонна у лестницы» выполнен в традициях кватрочентистской скульптуры низкого рельефа. Вероятно, при разработке этого образа Мадонны Микеланджело вдохновлялся античными стеллами и работами позднего Донателло, во многом близкими 
Антонио Пуччи, Лоренцо Медичи Великолепный, Франческо Сассетти и его сын Теодоро. $\Rightarrow$ Фрагмент фрески Доменико Гирландайо «Утверждение устава францисканского ордена». 1470 -е гг. Церквь Санта Тринита, капелла Сассетти, Флоренция.

Период Высокого Возрождения представляет собой зенит эпохи Ренессанса, кульминацию всей этой великой культуры. В отличие от предшествующего ему периода Раннего Возрождения, который занимал почти весь XV век (его итальянское наименование - кватроченто), хронологическая протяженность Высокого Возрождения невелика и составляет всего лишь несколько десятилетий - с конца XV века примерно до 1530 года. Однако даже в количественном отношении - в смысле обилия и крупных масштабов созданных в это время памятников искусства, не говоря уже об их высочайшем художественном уровне и колоссальном историческом значении, - об этих нескольких десятилетиях можно было бы сказать, что они стоят иных веков.

От предшествующего периода образы Высокого Возрождения отличаются прежде всего своей масштабностью. Внешне это проявляется в том, что наряду с распространением в архитектуре, живописи и скульптуре произведений крупных форм, появляются также образы гигантских масштабов, примерами которых могут служить «Давид» Микеланджело и его же огромные фигуры пророков и сивилл в росписи плафона Сикстинской капеллы. Каждый образ несет на себе отпечаток особого величия, что связано с еще одной особенностью искусства Высокого Возрождения - обощенностью художественного языка, стремлению к синтезу, к обощению. Пафос аналитического исследования натуры во всех ее подробностях, свойственный искусству Раннего Возрождения, уступил место мощному синтетическому порыву, извлекающему из явлений действительности самое их существо. Основное место занимает собирательный образ идеально-прекрасного человека, совершенного физически и духовно. Но эта идеальность образов означала максимально концентрированное выражение качеств самой действительности. Не говоря уже о героях ярко драматического склада, даже в образах, исполненных гармонической ясности, ощущается огромная внутренняя сила человека, спокойное сознание своей значительности. В соетании с крупным масштабом эти качества сообщают образам Высокого Возрождения подлинно титанический характер, ту степень героической действительности, которой никогда не достигало искусство ни Раннего, ни Позднего Возрождения.

ему по духу. Однако в отличие от мастеров XV века он отходит от жанровой трактовки сюжета и создает величественный образ, полный сдержанной внутренней мощи. В рельефе «Битва кентавров», тема которой была явно навеяна произведениями знаменитого гуманиста и поэта Анджело Полициано, Микеланджело впервые обращается к теме борьбы, которая станет одной из центральных в его творчестве. «Поразительная пластическая энергия рельефа «Битва кентавров», обилие и разнообразие мотивов движений обнаженных тел, сложное и свободное размещение кажущихся округльми фигур - во всем этом Микелан- джело предвосхищает не только приемы, но и сюжетные и композиционные мотивы своих будущих произведений. Перефразируя известное изречение, можно сказать, что, как весь дуб заключен в желуде, так весь последуюший Микеланджело содержится в этом юношеском рельефе, - недаром сам скульптор питал кәтому произведению особую привязанность на протяжении всей своей долгой жизни - писал Е.И. Ротенберг.

Испытывая зависть к успехам Микеланджело, один из учеников Бертольдо, Пьетро Торриджано, обладавший недюжинной силой, который, по рассказу Вазари, «постоянно искал случая оскорбить его делами

\section{Испытывая зависть к успехам Микеланджело, один} из учеников Бертольдо, Пьетро Торриджано, обладавший недюжинной силой, который, по рассказу Вазари, «постоянно искал случая оскорбить его делами либо словами», однажды устроил драку и так сильно ударил Микеланджело по лицу, что «навсегда его отметил сломанным и безобразно раздавленным носом». 

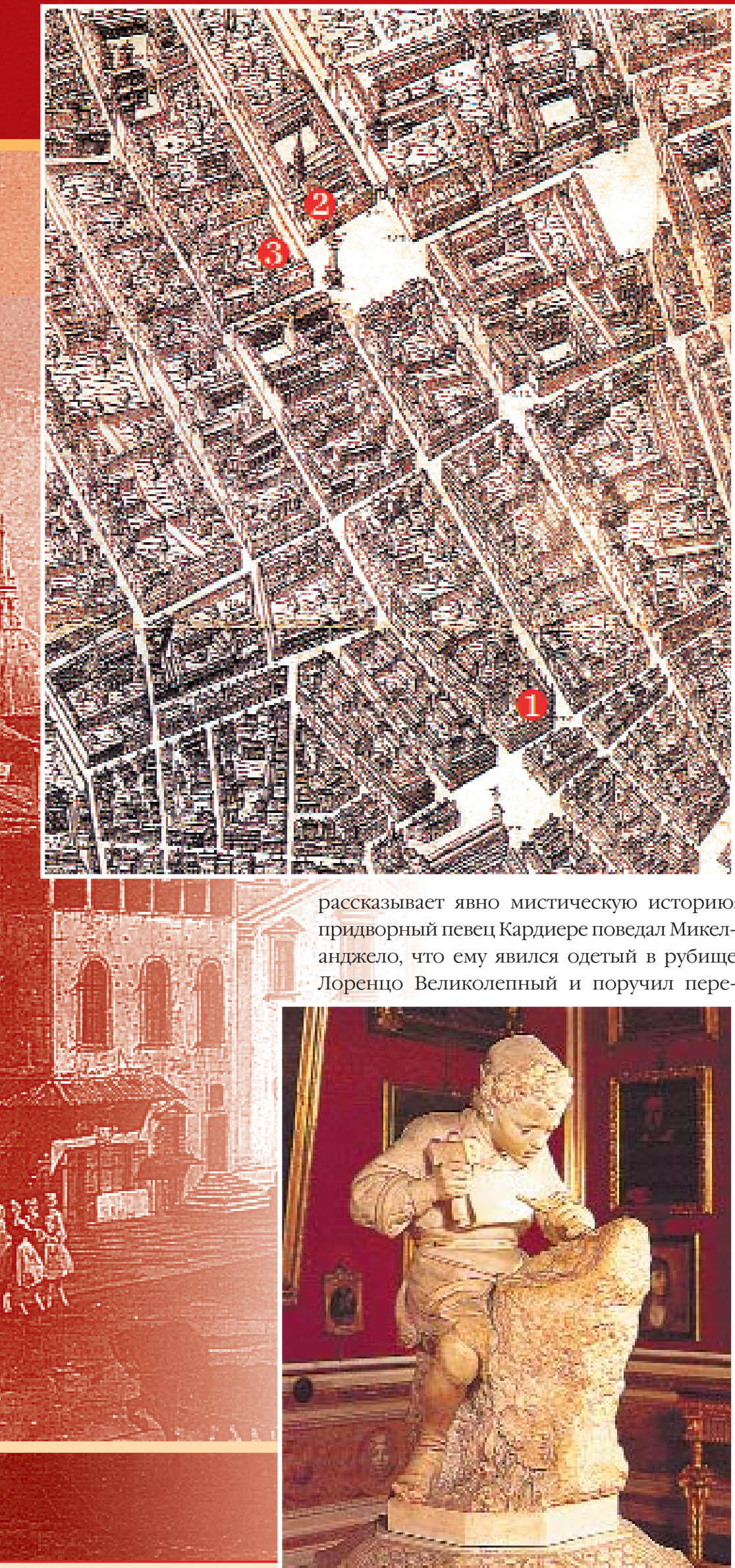

рассказывает явно мистическую историю: придворный певец Кардиере поведал Микеланджело, что ему явился одетый в рубище Лоренцо Великолепный и поручил пере-

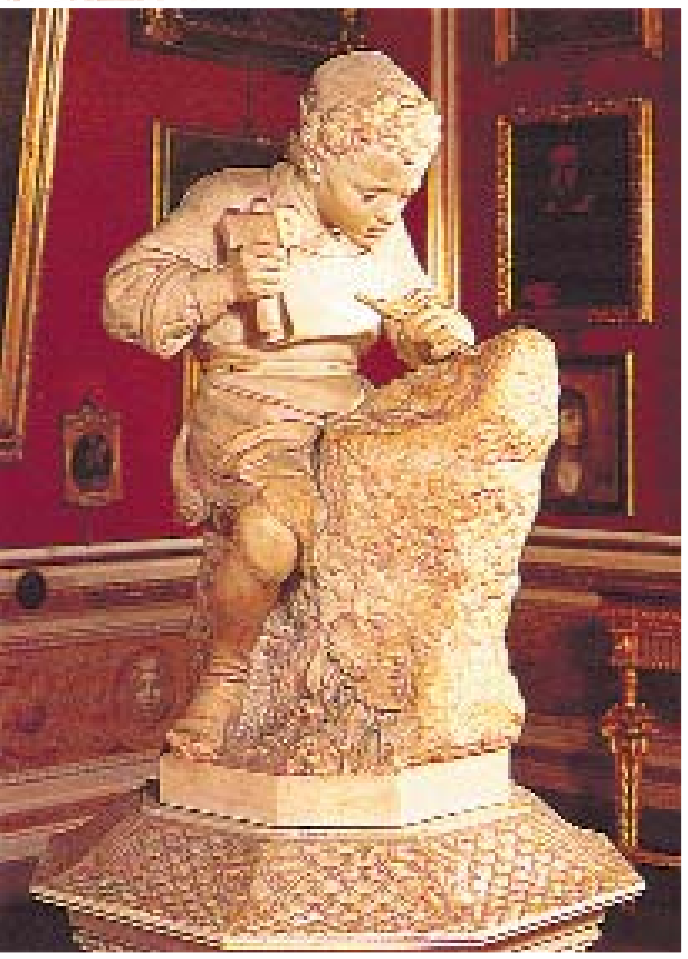

Фрагмент «Карты Флоренции»

Стефано Буонсиньори. 1584 г.

1 - Палаццо Медичи; 2 - монастырь Сан-Марко

3 - сады Медичи.

Микеланджело показывает $\Rightarrow$ Лоренцо Великолепному сделанный им бюст фавна. Фреска Оттавио Ваннини. 1635 г.

Палаццо Питти, Флоренция.

дать своему сыну Пьеро, что вскоре он будет изгнан из своего дворца и больше туда не вернется. Через некоторое время видение повторилось, причем певец утверждал, что Лоренцо ударил его по лицу, за то, что он до сих пор не передал предостережения его сыну. По совету Микеланджело, Кардиере наконец решился сказать обо всем Пьеро Медичи, однако тот поднял его на смех и проигнорировал предостережение - зато Микеланджело отнесся к нему со всей серьезностью и через два дня уехал из Флоренции.

Помимо предполагаемых мистических откровений за этим отъездом стояли вполне прозаические причины. Со смертью Лоренцо Медичи 8 апреля 1492 года Микеланджело лишился сильного покровителя. Затем наступили дни Савонаролы, Медичи были изгнаны из Флоренции, а общая обстановка в городе накалялась с каждым днем. По словам Кондиви, политические симпатии Микеланджело были всецело на стороне Савонаролы, «к которому он всегда питал большую любовъ, и пламенный голос которого у него навсегда остался в памяти». Однако о его связях с семьей Медичи было всем известно, поэтому в сложившихся условиях решение временно покинуть родной город представлялось наиболее разумным.

Сначала он посетил Болонью, затем Венецию, потом вновь вернулся в Болонью, где случайно нашел покровителя в лице местного патриция Джанфранческо Альдовранди, в доме которого и прожил до конца 1495 года. В Болонье Микеланджело изучал творения Данте, Петрарки и Бокаччо. Под влиянием канцон Петрарки он написал свои первые стихи. Альдовранди поручил ему закончить скульптурную композицию

Юный Микеланджело, высекающий голову фавна. Скульптор Эмилио Цокки. Около 1862 г.

Галерея Палатина, Флоренция. 


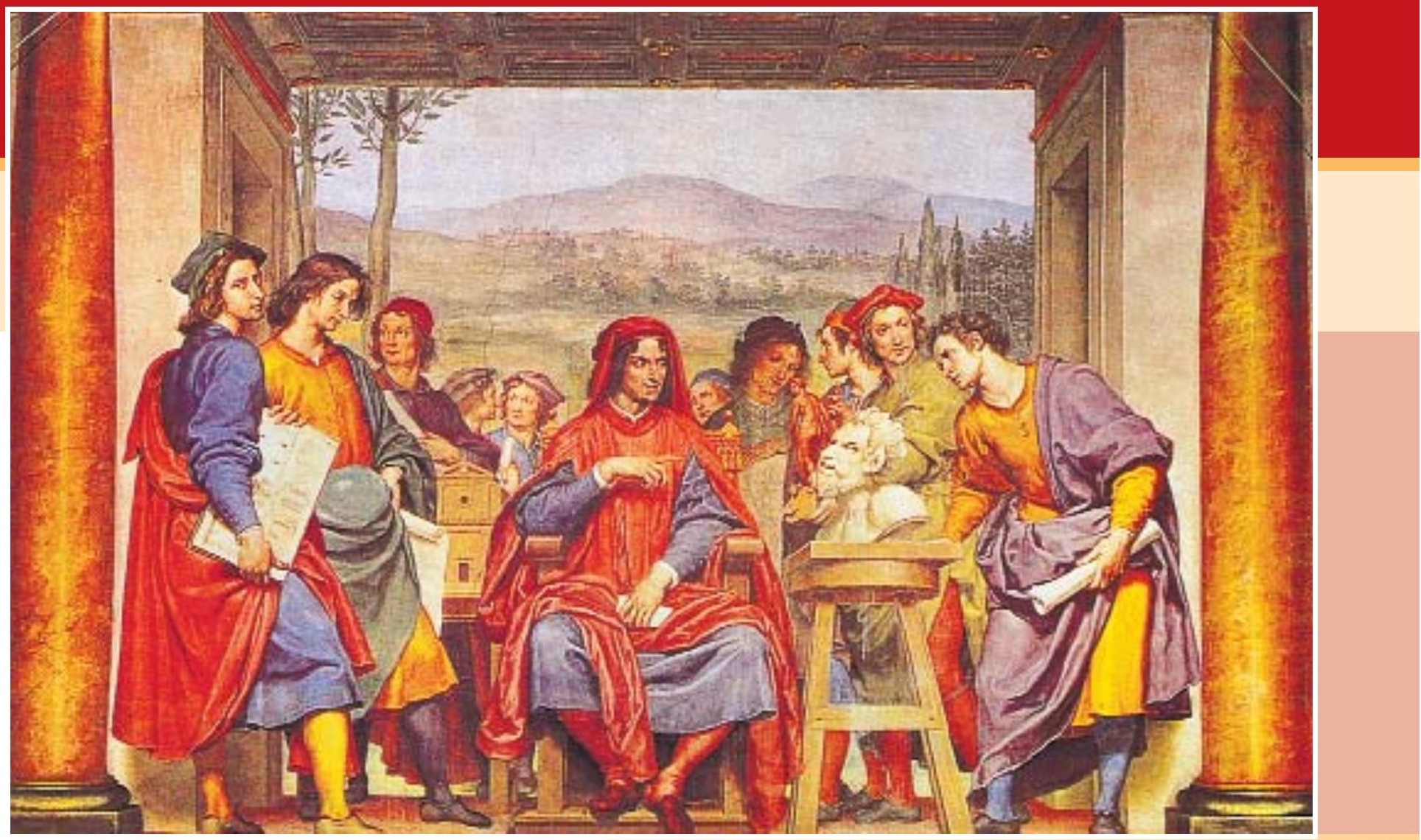

раки Св. Доминика ${ }^{6}$ - сделать статуи коленопреклоненного ангела с подсвечником, Св. Петрония и Св. Прокла.

В 1495 году Микеланджело вернулся во Флоренцию, где его заказчиком стал Лоренцо ди Пьерфранческо Медичи - двоюродный брат Лоренцо Великолепного, человек гуманистически образованный и большой любитель искусства. Его воспитателем и наставником был глава Платоновской академии Марсилио Фичино, по его заказу Боттичелли написал «Весну» и «Рождение Венеры», а Микеланджело сделал две небольшие статуи - «Спящего Купидона» и «Младенца Иоанна Крестителя» (обе не сохранились»). По совету все того же Пьерфранческо Медичи Микеланджело придал «Спящему Купидону» вид античной статуи, долго пролежавшей в земле, а затем продал ее за 200 дукатов богатому меценату и страстному
Политические симпатии Микеланджело были всецело на стороне Савонаролы, «к которому Он всегда питал большую любовь». Однако о его связях с семьей Медичи было всем известно, поэтому в сложившихся условиях решение временно покинуть родной город представлялось наиболее разумным.

коллекционеру кардиналу Рафаэлло Риарио, племяннику папы Сикста IV (1471-1484 гг.). Однако посредник, отвозивший статую в Рим, решил обмануть его и уплатил лишь ничтожную часть полученной суммы. Между Микеланджело и посредником разразился скандал, в результате

Бюст сатира. Флорентийская школа. Конец XV в. Национальный музей Барджелло, Флоренция.

Саркофаг был выполнен еще в ХІІІ в. знаменитым скульптором Никколо Пизано. Прим.ред.

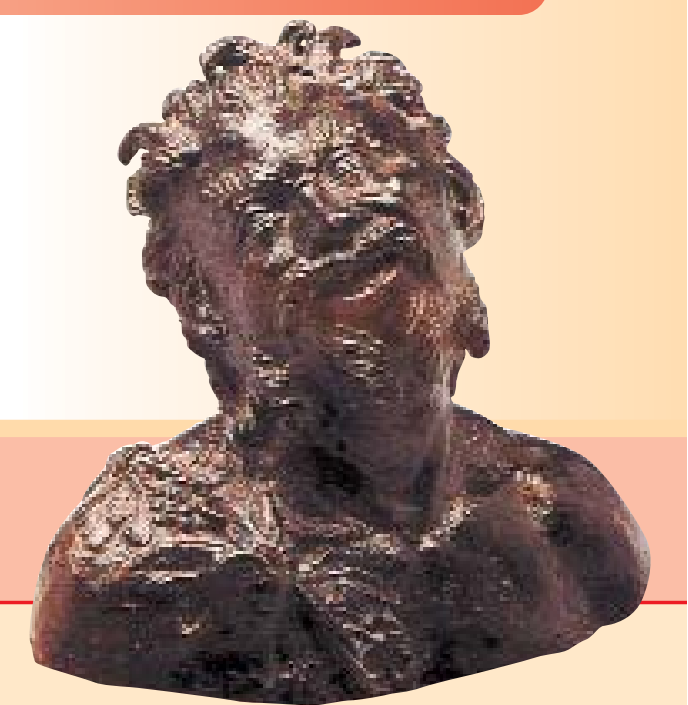




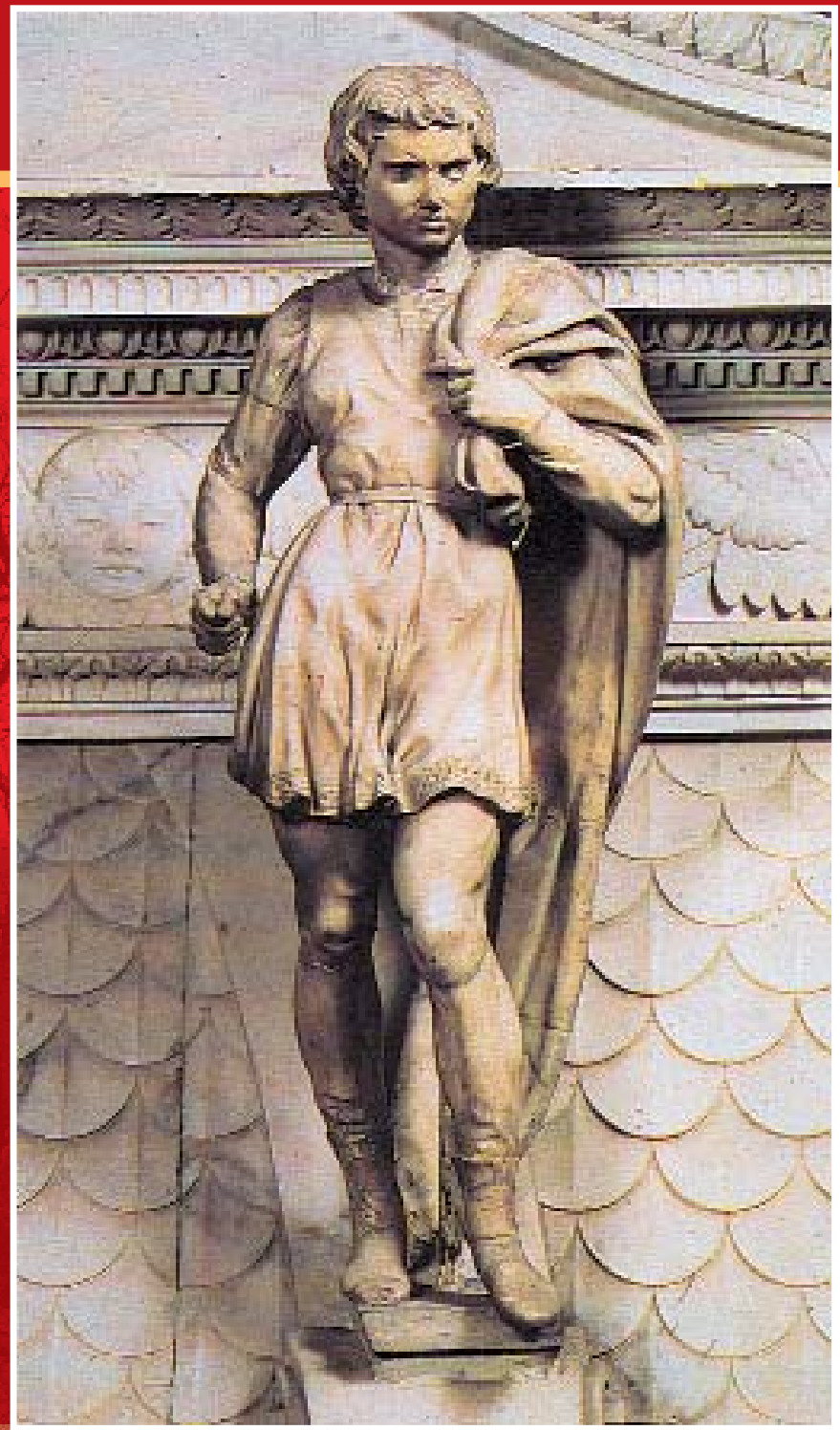

которого кардинал отказался от покупки, но благодаря этой уловке начинающий скульптор, «уличенный» в невиданном мастерстве, в 1496 году получил приглашение в Рим. Судя по всему, Микеланджело вообще был склонен к подобного рода авантюрам: еще во время учебы у Гирландайо он так виртуозно копировал рисунки старых мастеров, что, придав им ветхий вид, успешно выдавал за оригиналы.

Св. Петроний. Скульптура Микеланджело для раки Св. Доминика. 1494 г. Мрамор. Базилика Св. Доминика, Болонья.

Этот факт известен со слов Вазари: «Он воспроизводил также собственноручные рисунки различных старых мастеров так схоже, что можно было ошибиться, ибо дымом и разными другими вещами он подкрашивал их, придавая старый вид, и пачкал так, что они действительно казались старыми и, при сравнении их с подлинными, один от других отличить было невозпожно. И делал он это только для того, итобы, возвратив воспроизведенные, заполучить подлинные рисунки, которые его восхищали совериенством искусства, и которые он пытался превзоити своей работой, чем и приобрел иирочайшую известность..
Св. Прокл. Скульптура Микеланджело для раки

Св. Доминика. 1494 г. Мрамор.

Базилика Св. Доминика, Болонья.

В Рим Микеланджело приехал 25 июня 1496 года. К этому времени были уже открыты многие знаменитые античные памятники, в том числе «Лаокоон» и «Бельведерский торс», и Микеланджело был буквально захвачен образами античного искусства. Он отдал им дань в своем «Вакхе», выполненном по заказу банкира Якопо Галли, заядлого коллекционера и большого любителя античности. В «Вакхе» было еще слишком много ученического копирования, не случайно первый обладатель статуи поставил ее в саду своей виллы в окружении антиков, которые, по выражению В.Н. Лазарева, «были ей сродни».

Крупнейшей работой Микеланджело первого римского периода является мраморная группа «Пьета», выдвинувшая молодого

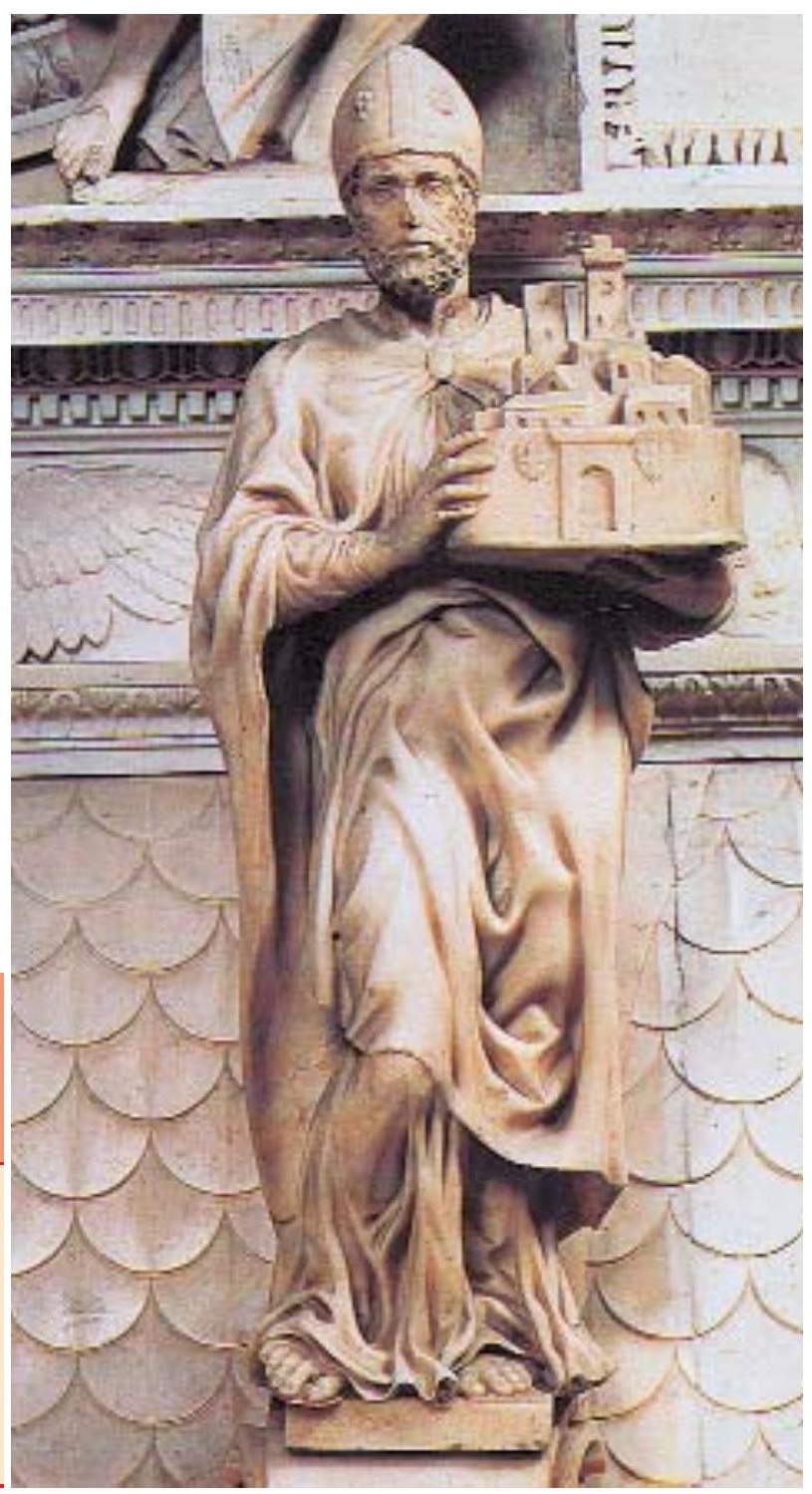


Ангел с канделябром. Скульптура Микеланджело для раки Св. Доминика. 1494 г. Мрамор.

Базилика Св. Доминика, Болонья.

По совету все того же Пьерфранческо Медичи Микеланджело придал «Спящему Купидону» вид античной статуи, долго пролежавшей в земле, а затем продал ее за 200 дукатов богатому меценату и страстному коллекционеру кардиналу Рафаэлло Риарио, племяннику папы Сикста IV (1471-1484 гг.)

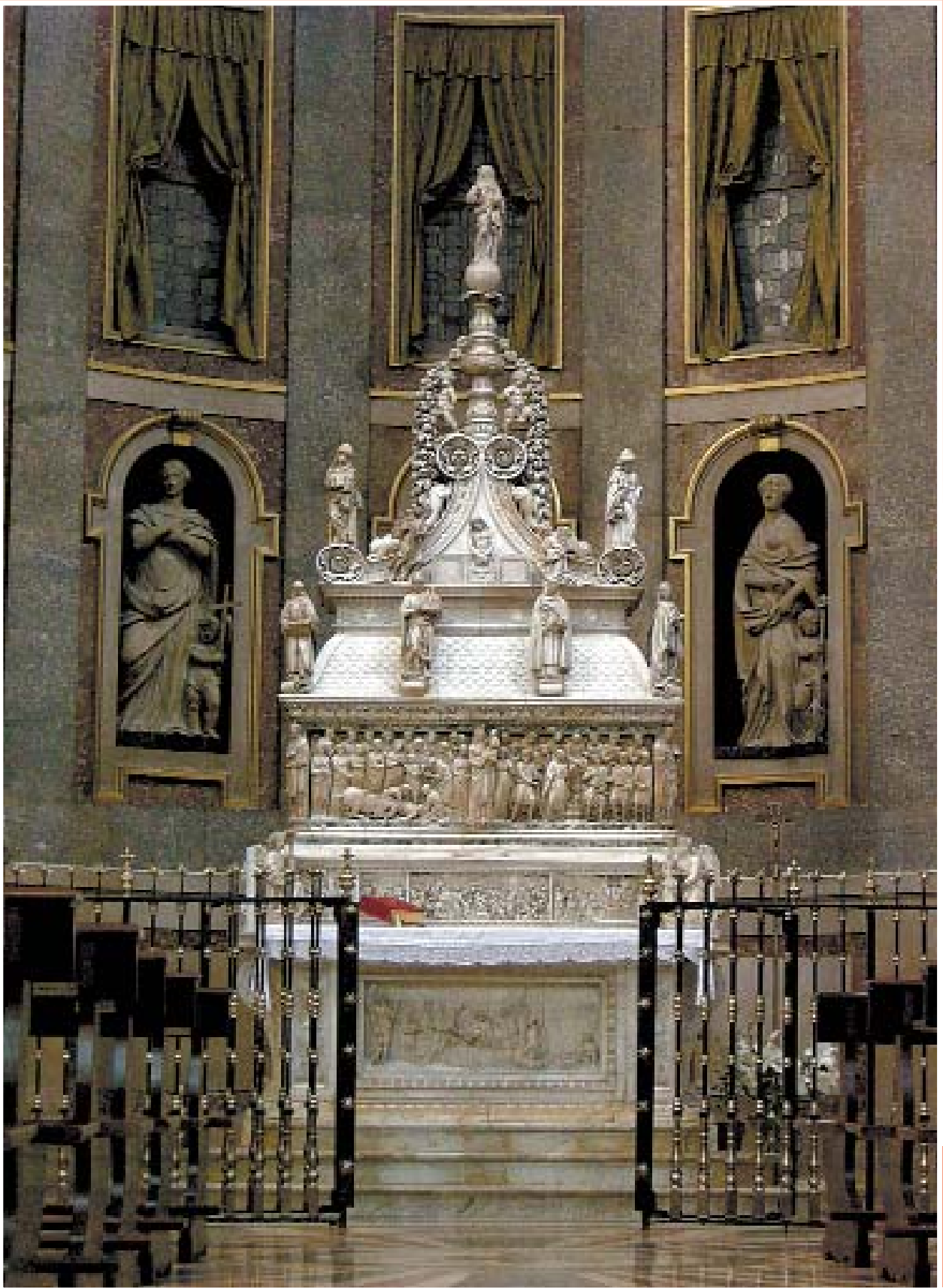

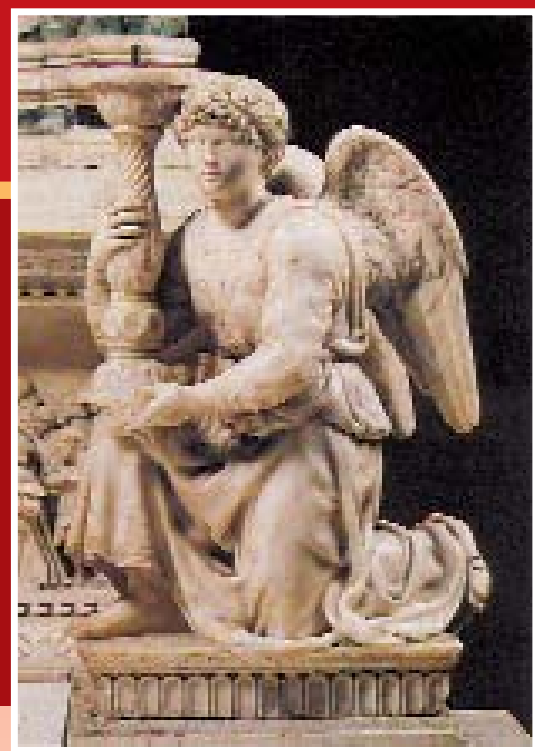

скульптора в число первых мастеров Италии. Заказанная французским кардиналом Жаном Бильером и впоследствии помещенная в соборе св. Петра, эта работа была единственным произведением Микеланджело, на котором он высек свое имя, утвердив тем самым себя полноправным мастером. По словам Кондиви, когда Микеланджело изваял это произведение, ему было 24 или 25 лет и после этого он приобрел большую известность и славу, ибо все понимали, что он не только превзошел всех своих современников, но мог соперничать и с древними мастерами. Гонорары Микеланджело росли: если за статую «Вакха» он получил около 150 дукатов, то за «Пьету» ему заплатили уже 450 дукатов, а заказ на украшение статуями алтаря собора в Сиене, который он получил от кардинала Франческо Тодескини-Пикколомини (в 1503 году ставшего папой Пием III), принес ему 500 дукатов, что во много раз превышало ставку обычного мастера.

Микеланджело вернулся во Флоренцию в 1501 году уже в статусе признанного мастера. Незадолго до его приезда, 24 апреля 1500 года, сюда же приехал и Леонардо да Винчи, за плечами у которого была уже созданная им в трапезной миланского монастыря Санта Мария

Рака Св. Доминика. Мрамор.

Базилика Св. Доминика, Болонья. 


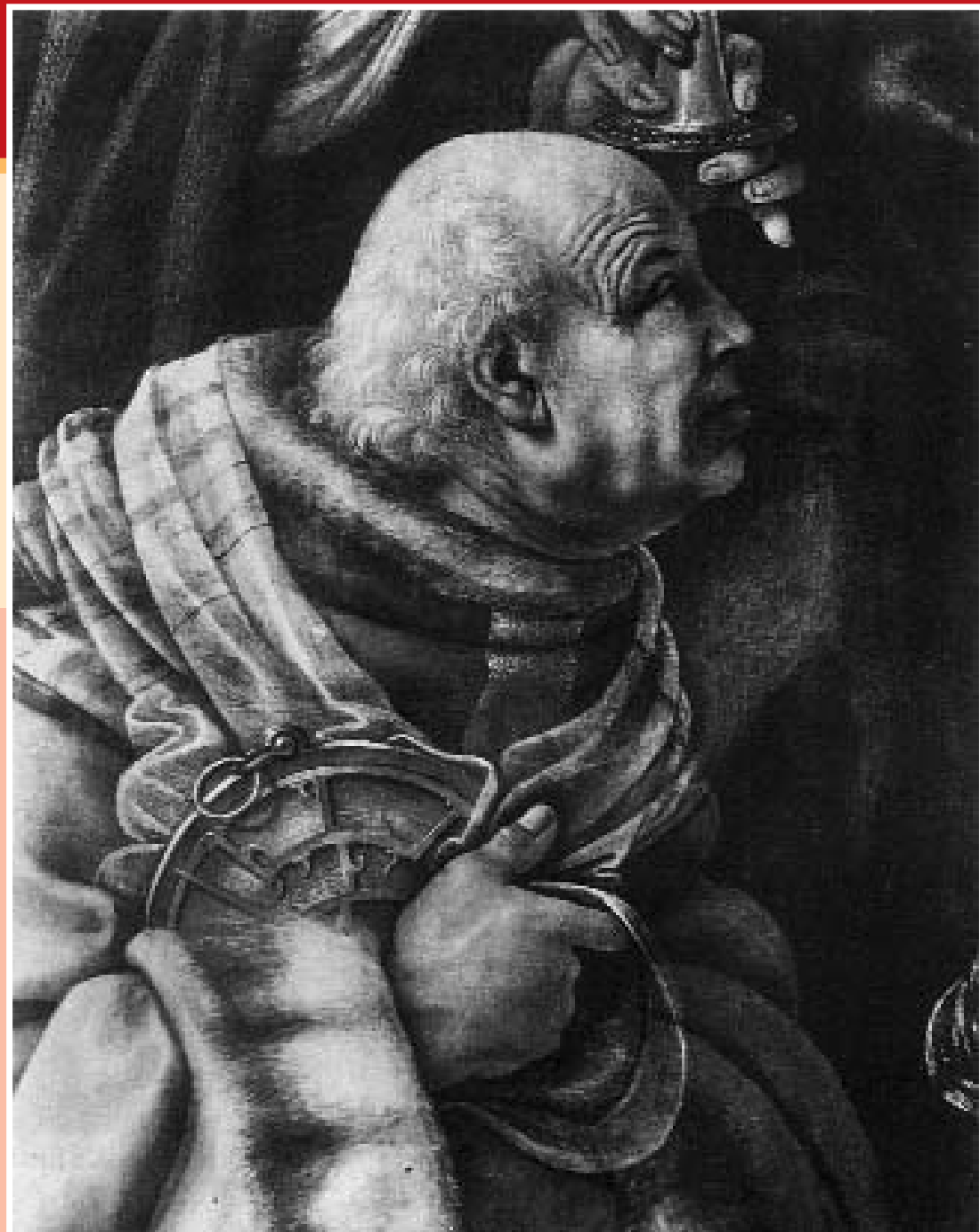

делле Грацие «Тайная вечеря», а слава о нем распространилась далеко за пределы Италии.

Контракт с кардиналом Пикколомини был первым крупным заказом Микеланджело после возвращения из Рима. По договору 1501 года он обязался выполнить за три года пятнадцать больших выше человеческого роста статуй: Христа, апос- толов и святых для ниш алтарной стены капеллы Пикколомини в Сиенском соборе. Эта работа затянулась на многие годы, став причиной постоянных терзаний загруженного другими заказами скульптора В настоящее время из сохранившихся статуй сиенского алтаря только три приписываются Микеланджело: Св. Павел, Св. Петр и Св. Пий.
Портрет Пьерфранческо Медичи.

Фрагмент картины «Поклонение волхвов».

Худ. Филиппино Липпи. 1496 г.

Галерея Уффици, Флоренция. Фрагмент фрески
«Месса в Больсене», Станца д'Элиодоро.
Худ. Рафаэль Санти. 1511-1514 гг. Ватиканский дворец, Рим.

В верхнем ярусе фрески можно увидеть коленопреклоненного папу Юлия II, ярусом ниже находится два кардинала, один из которых (на первом плане) Рафаэлло Риарио

Одновременно с этим заказом, а точнее - в августе 1501 года, старосты цеха шерстянщиков, попечители собора Санта Мария дель Фьоре, и его строительный комитет поручили Микеланджело изваять статую Давида, исполинская фигура которого в числе других должна была украшать контрфорс флорентийского собора. В качестве материала молодому скульптору предложили гигантский мраморный блок, который более двадцати пяти лет пролежал во дворе собора. Еще в конце XV века с ним начинал работать скульптор Агостино ди Дуччо, но, не справившись, испортил верхнюю часть блока. Как пишет Вазари, «мрамор был уже испорчен и изуродован», а «в некоторых местах его не хватало, чтобы Микеланджело мог сделать то, что он задумаль. Действительно, Микеланджело досталась мраморная глыба сильно вытянутой формы и неглубокой по своему объему. Скульпторы отказались ее использовать именно изза неудобной для работы формы. Но для подлинного гения это был настоящий вызов способностям, и Микеланджело подтвердил свою репутацию: он всегда мог «вписывать» фигуру в готовый блок камня так, чтобы она укладывалась в нем максимально экономно. Еще с юности ему было присуще уважительное отношение к камню. По его мнению, идеальный скульптурный образ скрыт внутрикаменного блока 


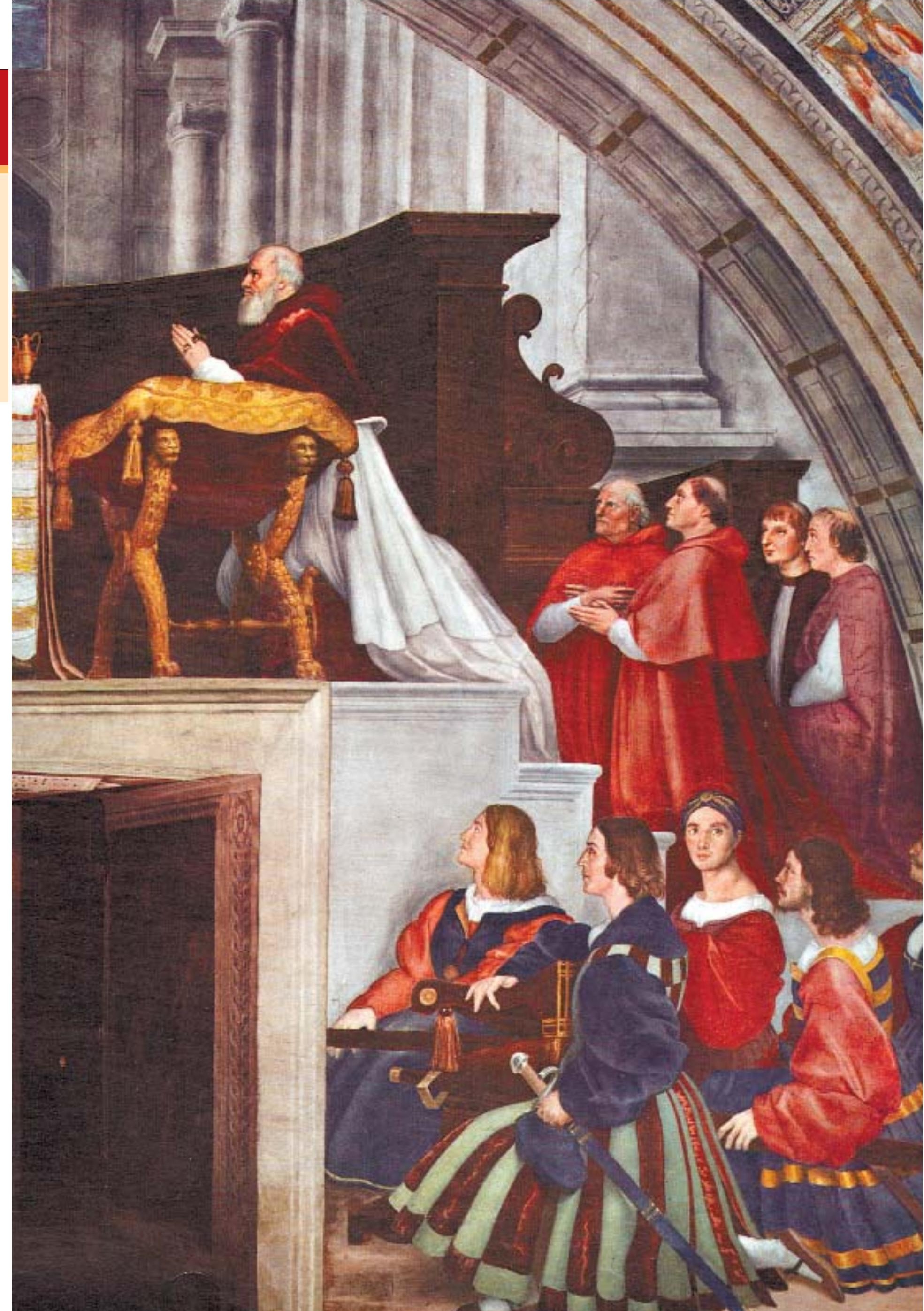




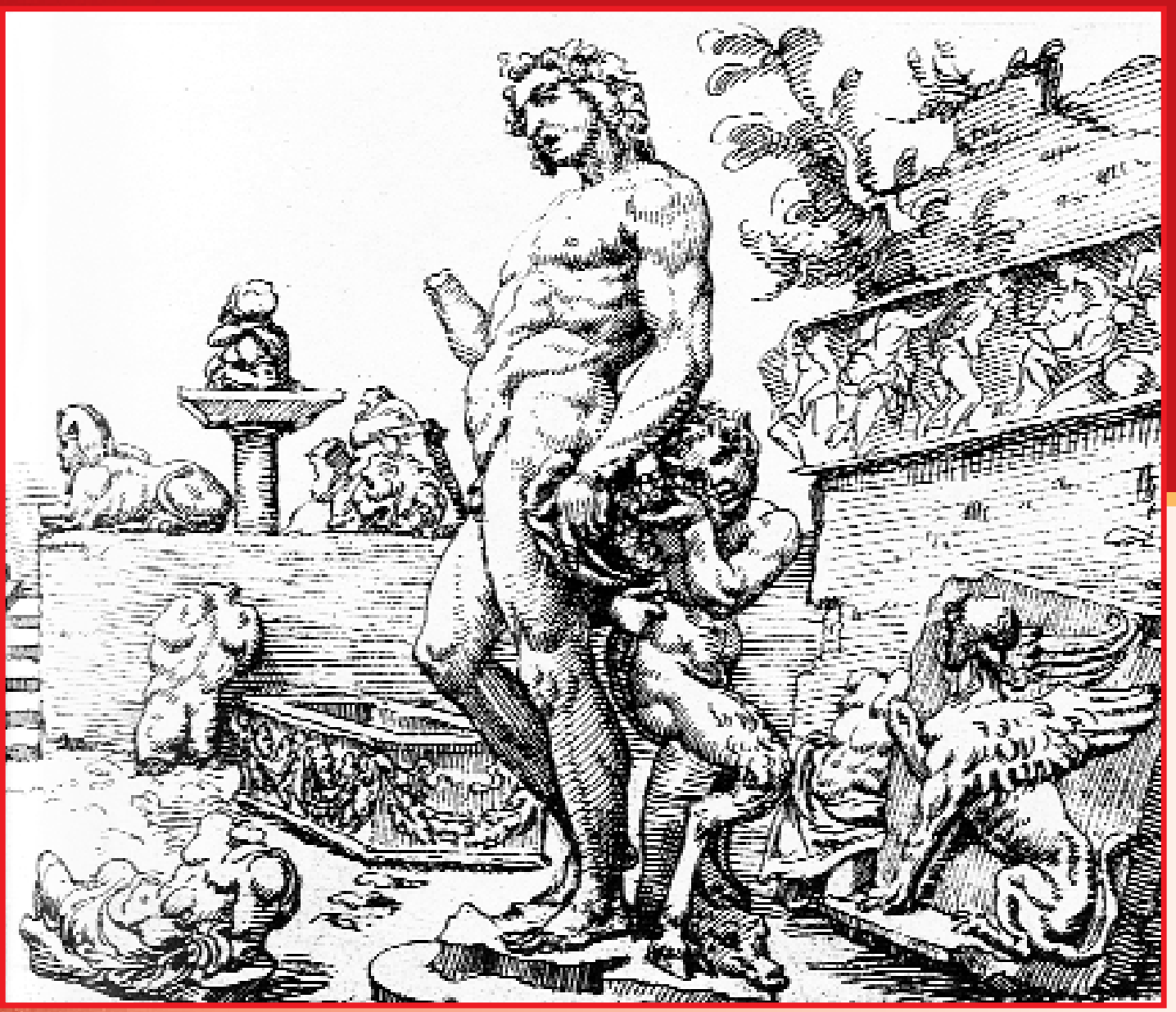

В «Давиде» Микеланджело возродил греко-римскую традицию монументальной пластики. Необычна и трактовка библейского образа: вместо робкого мальчика с угловатыми пропорциями отроческой фигуры Микеланджело изобразил Давида юношей, готовым к свершению подвига.

точно так же, как душа обитает в материальной оболочке тела. Искусство скульптора заключается в том, чтобы извлечь из камня этот образ, пробудить его кжизни. Подтверждение этой мысли можно найти в одном из знаменитых сонетов Микеланджело:

И высочайший гений не прибавит Единой мысли к тем, что мрамор сам Таит в избытке, - и лишь это нам Рука, послушная рассудку, явит. ${ }^{8}$

В «Давиде» Микеланджело возродил греко-римскую традицию монументальной пластики. Необычна и трактовка библейского образа: вместо робкого мальчика с угловатыми пропорциями отроческой фигуры Микеланджело изобразил Давида юношей, телом и духом готовым к свершению подвига.

Работа над «Гигантом», как назвали «Давида» флорентийцы, была отнюдь не из легких и заняла почти три года. Вместо предусмотренных 200, гонорар Микеланджело составил 400 скудо, однако достигнутый результат, по словам Вазари, все же не слишком впечатлил гонфалоньера: «случилось так, что Пьер Содерини, взглянув вверх на статую, очень ему понравившуюся, сказал микеланджело, который в это время ее кое-где отдельвал, что нос, по его мнению, у нее велик. Микеланджело, подме- 
Слева: Сад антиков Якопо Галли. Гравюра Мартена ван-Хемскерка. Около 1535 г. Кабинет гравюр, Прусское культурное наследие, Берлин.

Банкир Якопо Галли, выходеи из богатой и знатной римской семъи, получил прекрасное гуманистичекое образование. От своего предиественника, Джованни Галли, он унаследовал обширную коллекцию антиков, которую пополнил новыми приобретениями. В этой колекции, размещавиейся в саду его дома на Рионе Павионе, кроме «Вакха» находиласъ и другая ранняя работа

Микеланджело - несохранившаяся статуя «купидона».

Внизу: Вакх. Скульптура Микеланджело Буонарроти. 1496-1497 гг. Мрамор

Национальный музей Барджелло, Флоренция.

Для современников, как писал Кондиви, «Вакх» Микеланджело стал творением, «форма и внешний вид которого в каждой части соответствует мысли античных авторов». Тело бога, пошатывающегося от опьянения, проиводит впечатление юноческого и вместе с тем отлечено печатью женственности. Вазари заметил, что Микеланджело «хотелось добиться» подобного сочетания. Как предполагают, подчеркивая подобную двойственность, Микеланджело, хотел передать идею о том, что чувственность подобной божественной природы имеет для человека и оборотную сторону. В левой руке бог небрежно держит львиную икуру - символ смерти, и кисть винограда - символ жизни: вот так и человек, лииь короткое время находится в ситуапии паниска, вкуииающего виноград, меж тем как смерть - львиная икура - находится совсем близко. Обе они - ижизнь, и смерть - в руках божьих.

тив, что гонфалонъер стоял под самым гигантом и точка зрения его обманывала, влез, чтобы угодить ему, на подмостья у плечей статуи и, поддев резцом, который он держал в левой руке, немного мраморной пыли с площадки подмостьев, начал постепенно осыпать пыль вниз, работая будто другими резцами, но к носу не при-

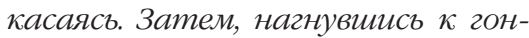
фалоньеру, который следил за ним, он сказал: «А ну-ка, посмотрите на него теперь». - «Теперьмне нравится больше, - сказал гонфалоньер, вы его оживили». Микеланджело спустился тогда с мостков, про себя над ним подсмеиваясь и сожалея о людях, которые, желая выказать себя знатоками, говорят такое, чего сами не понимают.

По решению экспертной комиссии, созванной 25 января 1504 года, монумент решили установить перед дворцом Синьории ${ }^{9}$ однако его транспортировка представляла значительные затруднения, выход из которых был найден следующим образом: братья Джулиано и Антонио да Сангалло устроили прочную деревянную башню, к которой подвесили статую на канатах так, чтобы при толчках она равномерно покачивалась, и передвигали ее по гладким бревнам при помощи лебедок на канатах. Установка «Давида» состоялась 8 сентября 1504 года. Она простояла перед дворцом Синьории почти 370 лет, пока в 1873 году

Имеется в виду палаццо Веккьо (итал. Palazzo Vecchio - Cmaрый двореи), который в XV веке назывался Palazzo della Signiria, поскольку флорентийские правители обвявили себя синьорами (signori). - Прим. ред. не был перенесен в Академию изящных искусств (сейчас - Галерея Академии), а в начале XX века ее место на площади заняла копия.

Около 1501 года Микеланджело выполнил статую Мадонны, приобретенную фламандским купцом Мускроном. Сейчас эта статуя ук- рашает алтарь церкви Нотр-Дам в Брюгге. По степени завершенности, исключительной тщательности отделки деталей и по характеру полировки мрамора эта работа близка к ватиканской «Пьете». К тому же времени относятся два мраморных тондо - «Мадонна Таддеи» и «Ма-
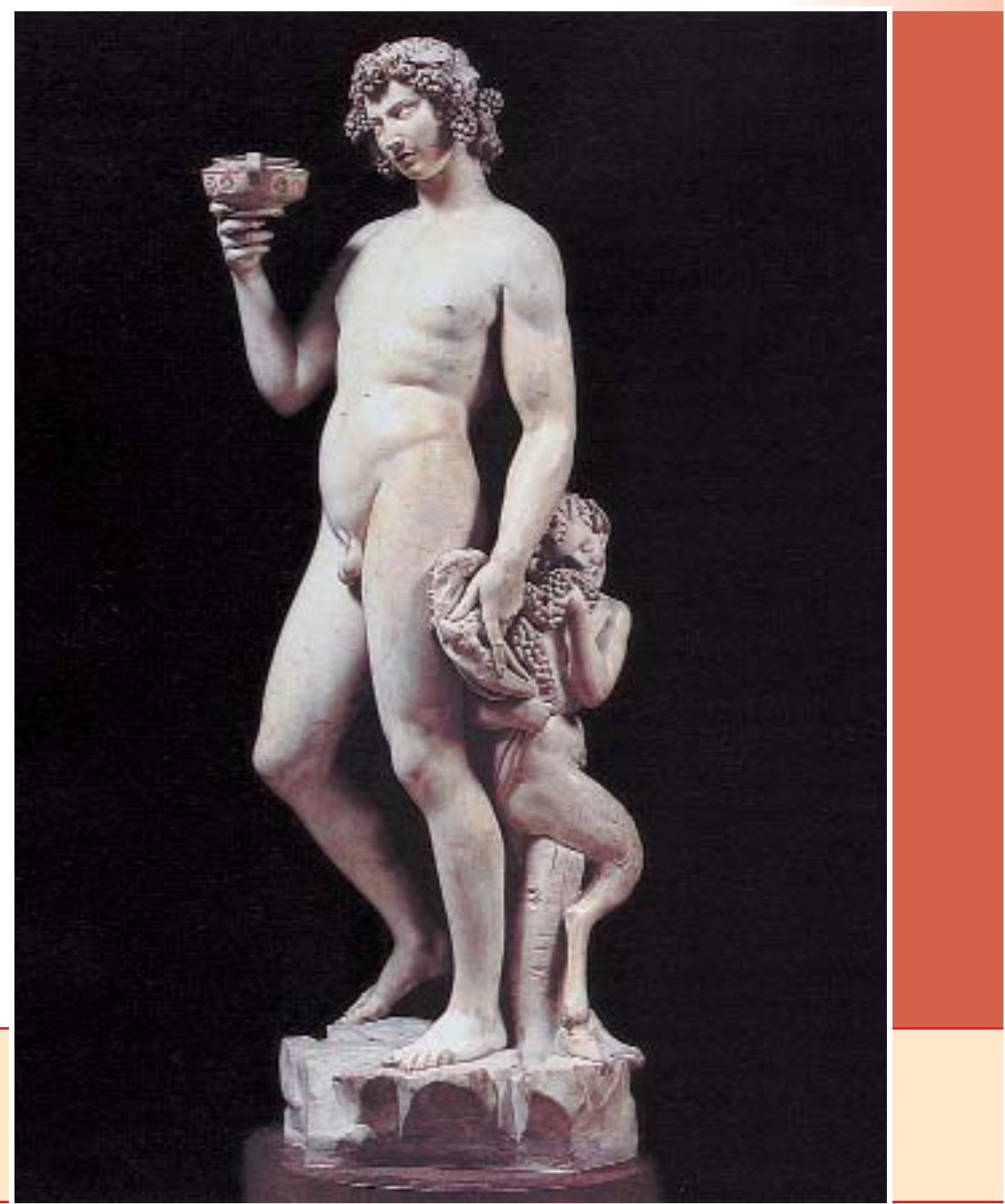


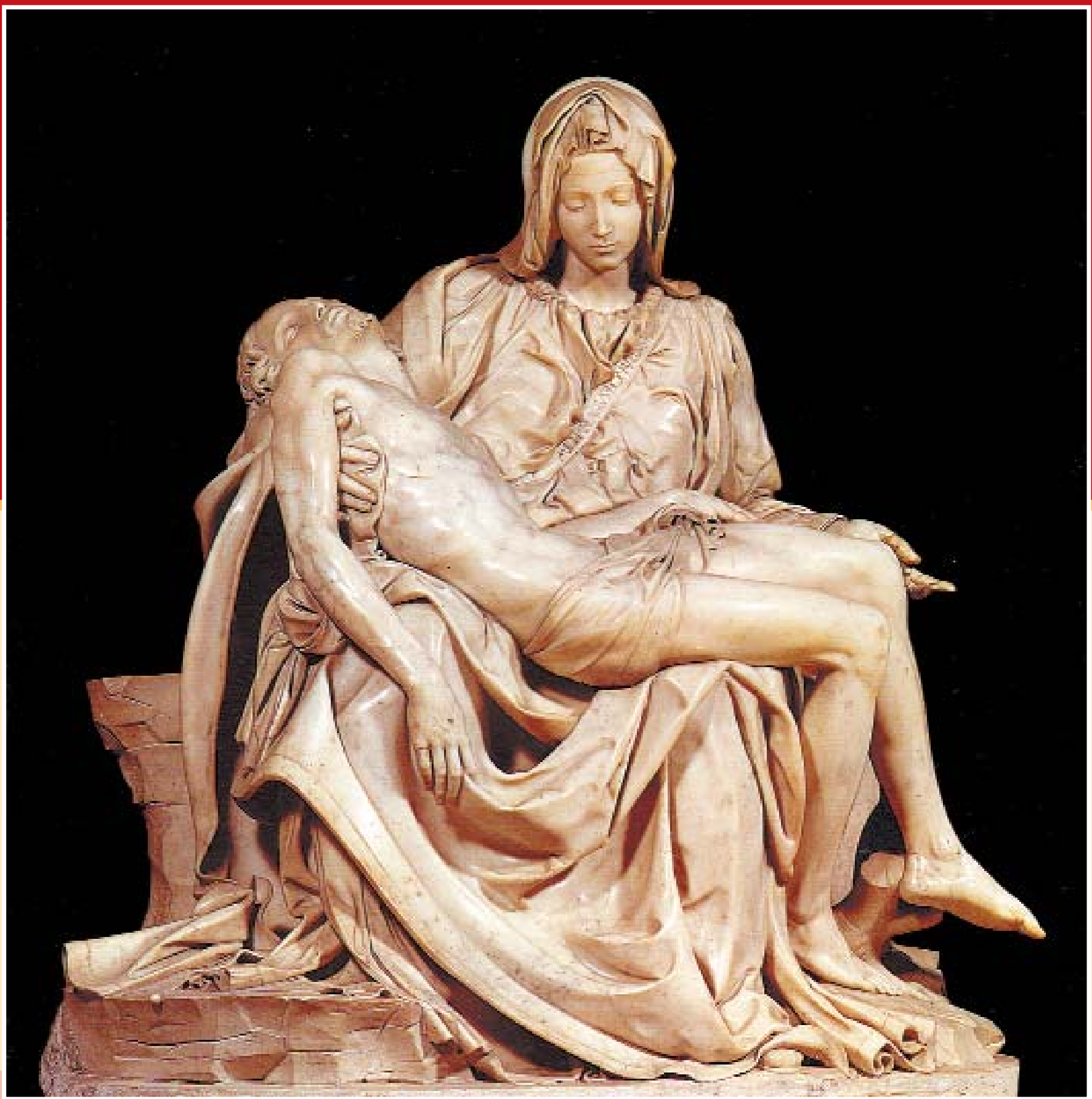

Пьета.

Скульптура Микеланджело Буонарроти. 1498-1499 гг.

Собор Св. Петра, Рим.

В римской «Пете» Микеланджело обратился к характерным для Северного Возрождения иконографическим прообразам, выбрав редкий для Италии тип изображения, восходящий к немецким деревянным статуям Марии с мертвьим Христом на коленях. Но в отличие от страдаюоих, изможденных, чаме всего немолодых мадонн северных прообразов он создал образ юной Марии-девы, горе которой отражается лишь в ее печали. донна Питти». Несмотря на схожесть сюжета - Мадонна с младенцем Иисусом и Иоанном Крестителем обе работы совершенно разные по настроению и трактовке образов. На тондо, выполненном для Братоломео Питти, Мария прижимает к себе младенца Христа, как бы оберегая его от врагов. Как у «Мадонны Брюгге» ее лицо выражает тревогу за судьбу сына. Мы видим здесь ту же зрелость, одухотворенностью, печаль и обреченность. Тондо, принадлежавшее Таддео Таддеи, напротив, излучает жизнерадостность. Здесь мы видим одно из редких для Микеланджело лирических жанровых решений. Молодая мать, задумчиво улыбаясь, смотрит на игру детей Иоанн Креститель протягивает щегленка Христу, а тот в испуге ищет защиты у матери. Этот прелестный мотив так понравился Рафаэлю, что он скопировал его в рисунке и дважды использовал в своих работах («Мадонна со щегленком», «Мадонна в кресле»).

В июле 1504 года правительство республики во главе с гонфалоньером $^{10}$ Пьетро Содерини поручил 


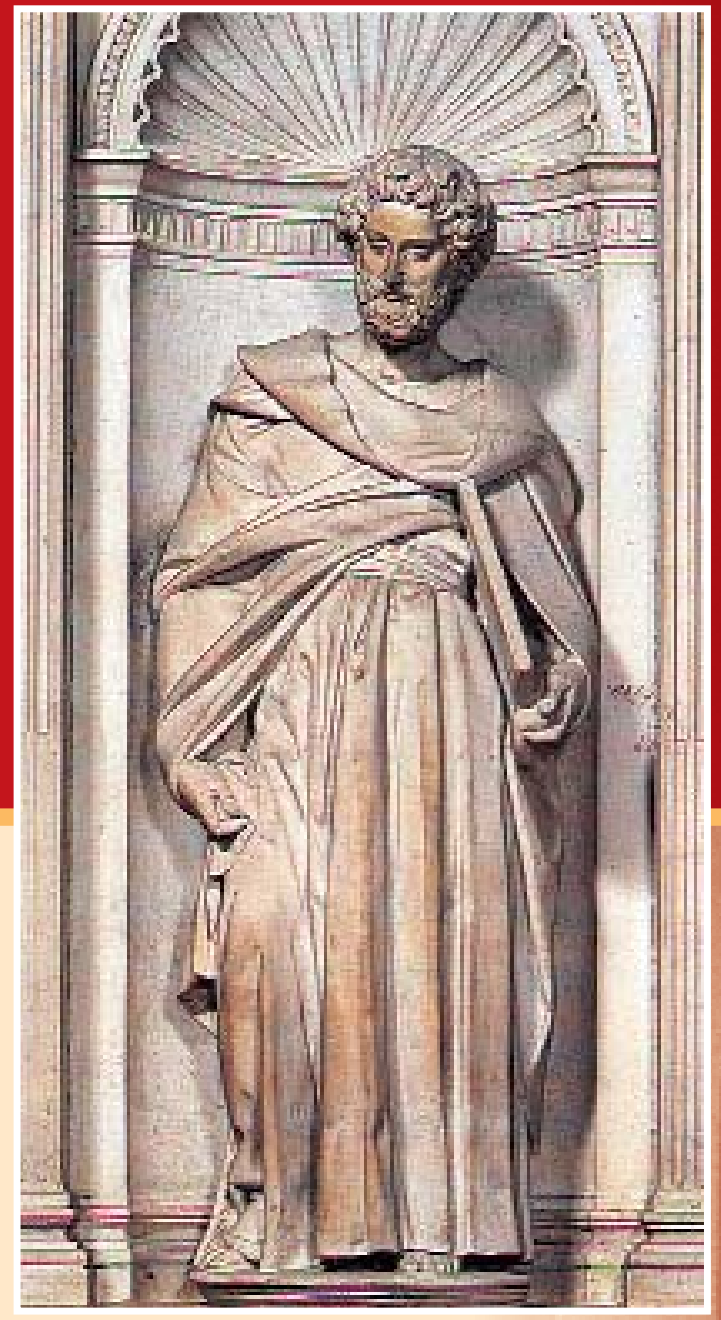

Bepxy:

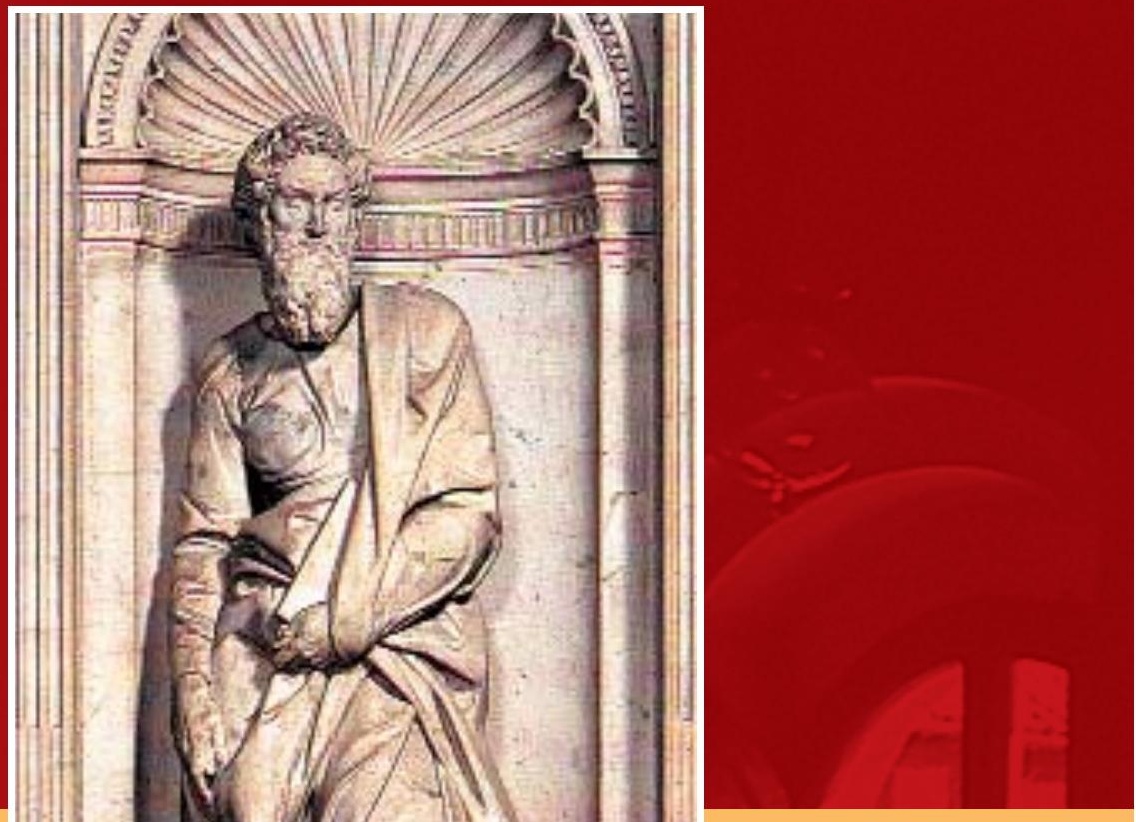

Слева: Св. Петр. Скульптура Микеланджело Буонарроти. 1503-1504 гг. Мрамор. Алтарь Пикколомини, Сиенский собор.

Справа: Св. Павел. Скульптура Микеланджело Буонарроти. 1503-1504 гг. Мрамор. Алтарь Пикколомини, Сиенский собор.

Микеланджело расписать одну из стен в Зале Большого совета (ныне Зал Пятисот) флорентийского дворца Синьории. Желая укрепить политическое положение Флоренции и утвердить ее воинскую славу и могущество в историческом прошлом, власти развернули работы по благоустройству и украшению города. Среди прочего было решено закончить отделку вновь отстроенного зала, в котором заседал Большой совет республики В этом зале обсуждались и решались все важнейшие вопросы внешней политики

Алтарь Пикколомини в Сиенском соборе. Общий вид.

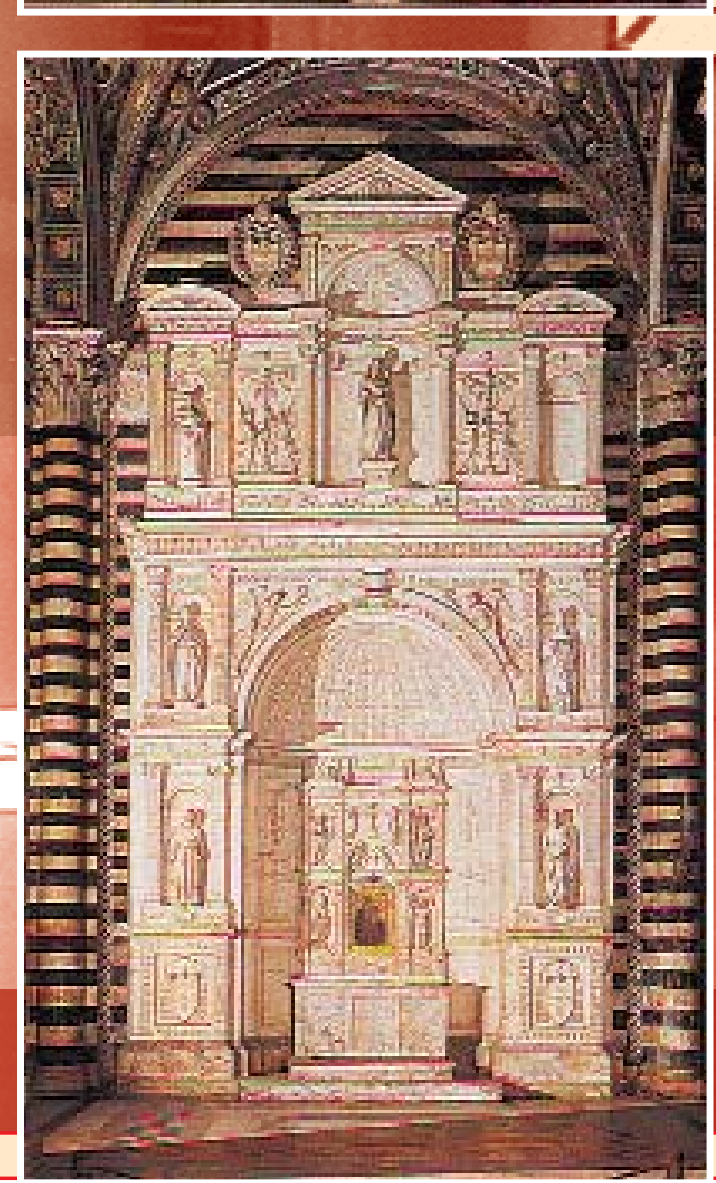




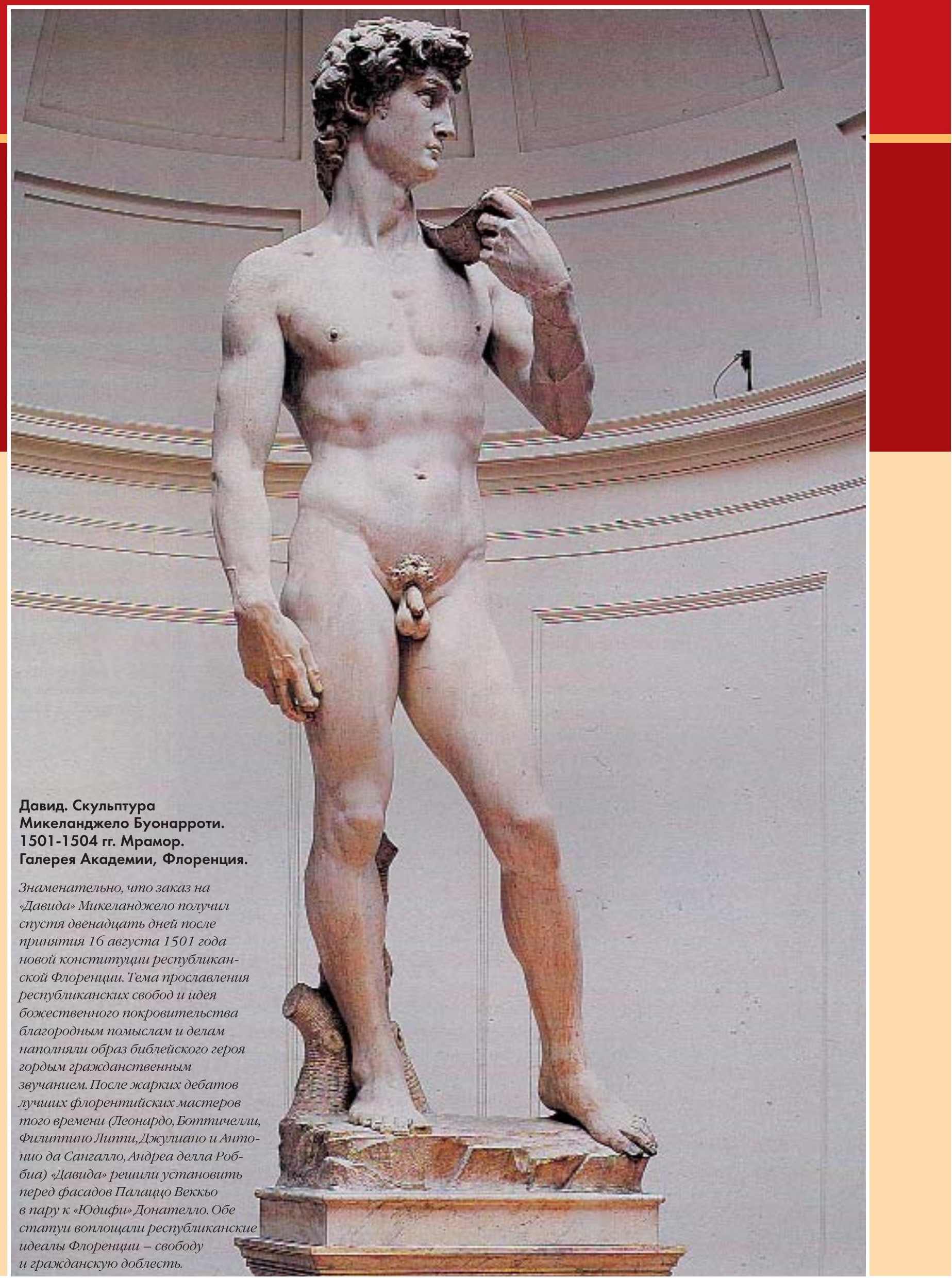


Модель телеги, сооруженной в 1873 году для передвижения «Давида» с площади Синьории в Академию изящных искусств. Неизвестный мастер. Дерево, гипс. Дом Буонарроти, Флоренция.

и городского управления, здесь вершилось правосудие и воздавались почести, поэтому понятно, почему богатые граждане города и члены Синьории так спешили с завершением его отделки.

Две расположенные друг против друга стены в зале было решено украсить росписями на темы из военной истории города. Выбрали два эпизода - победу флорентийцев над отрядом миланского герцога в битве при Ангиари 29 июня 1440 года и победу отряда Галеотто Малатеста над пизанцами

Внизу:

Площадь Синьории во Флоренции. Худ. Бернардо Беллотто. 1742 г. Музей изящных искусств, Будапешт.
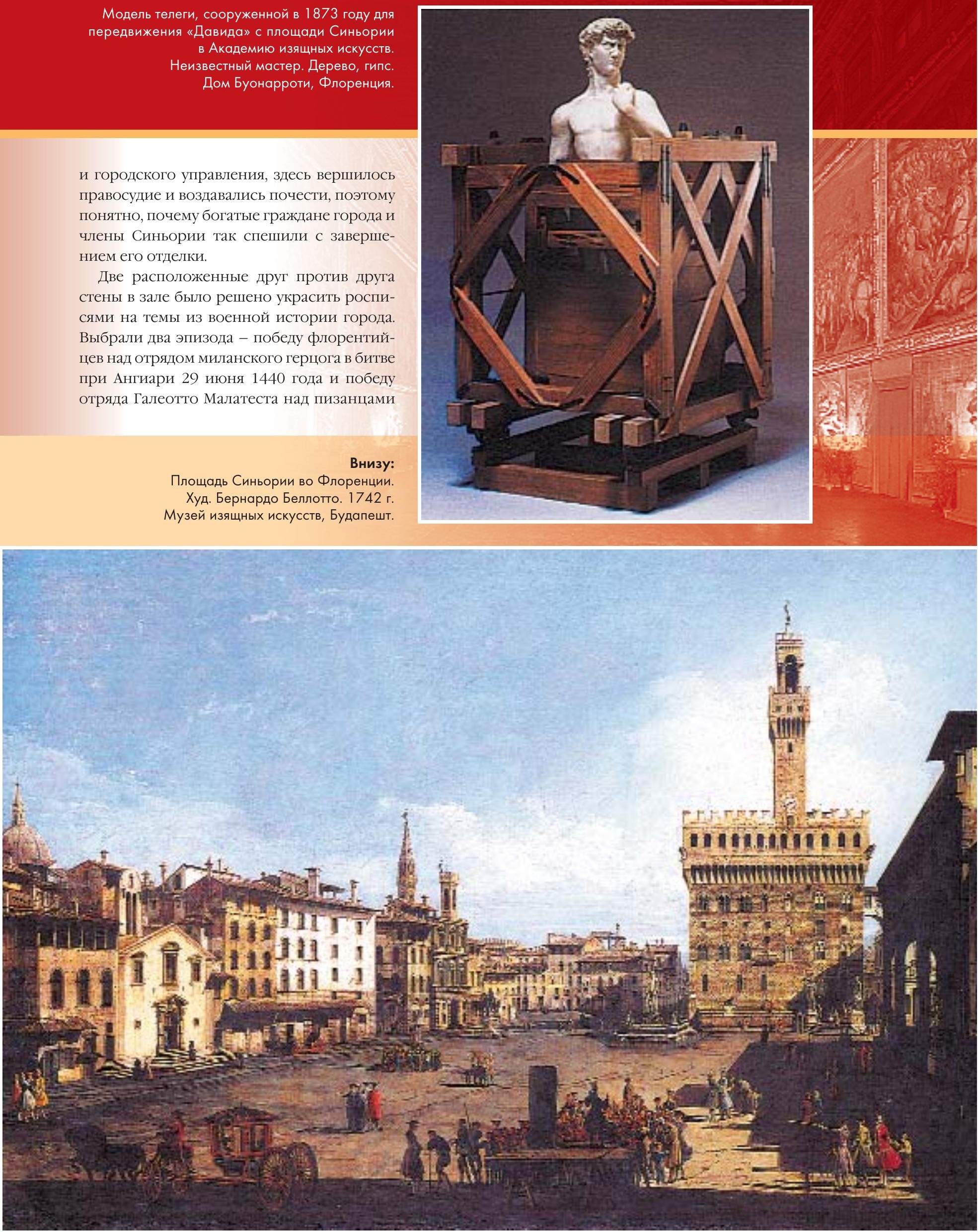


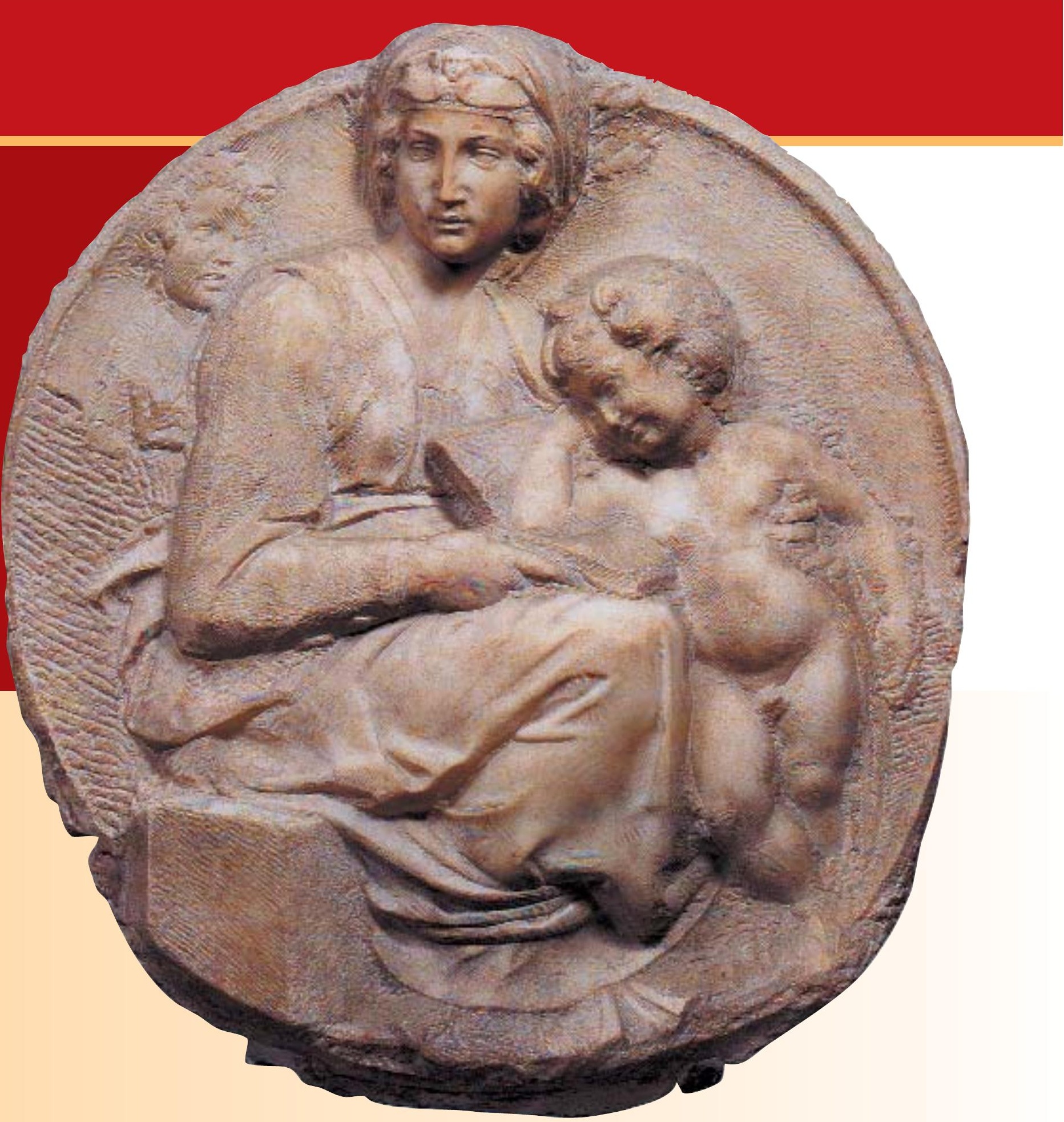

Мадонна Питти. Рельеф Микеланджело Буонарроти. Около 1503 г. Мрамор.

Национальный музей Барджелло, Флоренция.

в битве при Кашине 29 июля 1364 года. Одну из стен поручили расписать Леонардо да Винчи, другую, после долгих обсуждений и споров, - Микеланджело.

В силу разных причин ни одна из фресок так и не была выпол- нена. Со слов Вазари известно, что Микеланджело успел выполнить только подготовительный картон, который вызывал восхищения современников, но до наших дней не сохранился. ${ }^{11}$ Сейчас о подлинном замысле мастера можно толь- ко догадываться, поскольку даже на лучшей из дошедших до нас копий того самого картона, выполненной учеником Микеланджело Бастиано да Сангалло, скорее всего, изображен лишь фрагмент композиции.

' В 1515-1516 гг. копировавшие картон молодые художники разрезали его на отдельные куски, которые в дальнейшем погибли. Прим.ред. 


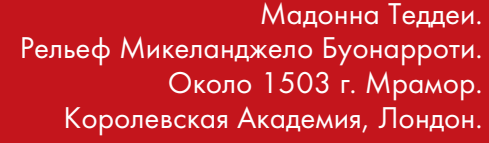

Темой для фрески Микеланджело послужил эпизод, подробно описанный в хронике Филиппо Виллани. 29 июля 1364 года флорентийская армия, воевавшая с пизанцами, разбила лагерь в предместье Кашины, на берегу реки Арно, неподалеку от Пизы. Стояла сильная жара; раздевшиеся воины, отложив в сторону оружие, отдыхали либо купались в Арно. Их начальник, капитан Галеотто Малатеста, еще не оправившийся от лихорадки, крепко спал. Внезапно раздался крик: «Mы пропали. Первым возвестил опасность Манно Донати, увидевший приближавшееся пизанское войско. Это послужило сигналом к тому, что все воины начали быстро одеваться, хватать оружие и готовиться к отражению атаки пизанцев. Данный момент и запечатлел в своем картоне Микеланджело.

В отличие от Леонардо, он избрал не кульминационный момент сражения, а эпизод, предшествовавший битве. Это дало ему возможность изобразить обнаженные фигуры мужественных воинов, готовых к героическому действию. Битве при Кашине республикански настроенная Флоренция придавала большое значение, так как она символизировала победу гвельфской партии, которой Микеланджело неизменно симпатизировал. Поэтому изображение этой битвы в Зале Совета имело свой глубокий политический смысл.

Помимо правительственных, Микеланджело выполнял во Флоренции и частные заказы. Об одном из них, красноречиво иллюстрирующем не только грани таланта, но и грани характера Микеланджело, пишет Вазари, рассказывая, что один из друзей, Аньоло Дони, заказал ему круглую картину (tondo) с изображением Святого семейства; по завершении, Микеланджело отослал ее в завернутом виде на дом к Аньоло с посыльным и доверенностью с просьбой уплатить ему

70 дукатов. «Анъоло, который был человеком расчетливым, показалось странным тратить такие денъги на картину, хотя и понимал, что она стоит еще дороже; $и$ он заявил посьльному, что достаточно будет и сорока, каковые ему u передал. Но Микеланджело прислал их обратно, наказав посыльному назначить 100 дукатов или принести картину обратно. На что Аньоло, которому работа понравилась, заявил: «Дай ему семь- десят». Но он и этим остался недоволен: более того, из-за малого доверия Анъоло он потребовал с него вдвое против того, ито просил вначале, почему и пришлось Анъоло, которому хотелось получить картину, послать ему 140 скудо". В историю искусства эта картина вошла как «Мадонна Дони».

В марте 1505 года новый римский папа Юлий II (1503-1513 гг.) пригласил Микеланджело в Рим, поручив ему создание своей гробницы,

\section{Битве при Кашине республикански наст- роенная Флоренция придавала большое значение, так как она символизировала победу гвельфской партии, которой Микеланджело неизменно симпатизи- ровал. Поэтому изображение этой битвы в Зале Совета имело свой глубокий политический смысл.}




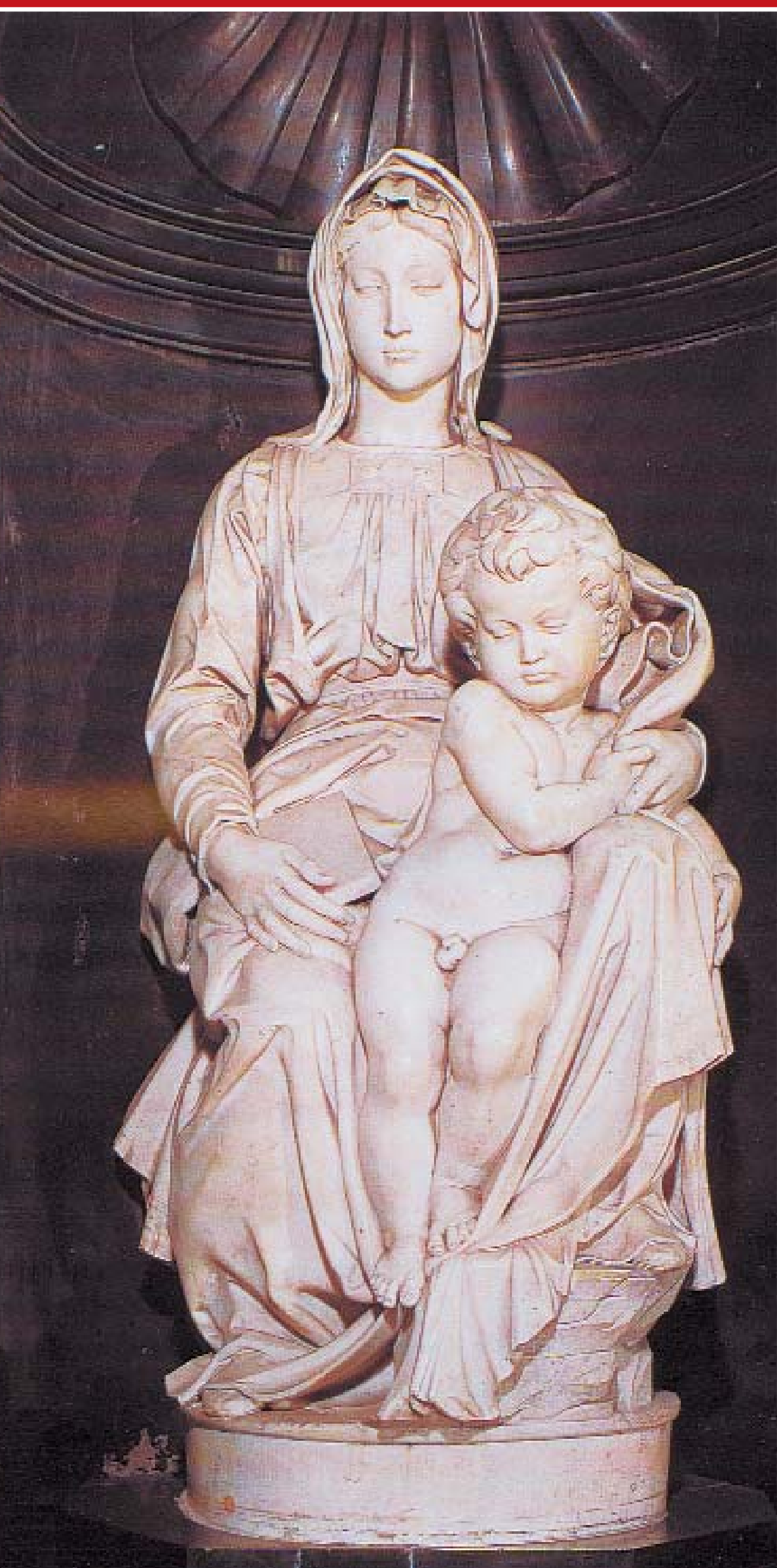

Мадонна с младенцем.

Скульптура Микеланджело Буонарроти.

1503-1504 гг. Мрамор.

Церковь Нотр-Дам, Брюгге.

\section{Худ. Микеланджело Буонарроти. 1503-1504 гг. \\ Галерея Уффици, Флоренция.}

которую предполагалось расположить в хорах старой базилики Св. Петра. По замыслу папы, его гробница должна была по размерам и богатству оформления превзойти все подобные сооружения, созданные прежде. Предполагалось, что это будет свободное стоящее (а не прислоненное к стене) сооружения, украшенное сорока гигантскими статуями и рельефами. Утвердив у папы эскизы, Микеланджело отправился за мрамором в Каррару, где провел целых восемь месяцев (с апреля до декабря 1505 года).

Проект гробницы Юлия II оказался не менее многострадальным, чем знаменитый миланский конный памятник Леонардо да Винчи: за 40 лет с момента начала работ Микеланджело заключил пять договоров на их исполнение, налагавших на него различные обязательства, которые послужили причиной его столкновений с папой, а впоследствии с его племянником, Франческо Марией делла Ровере, герцогом Урбино, и сыном последнего, Гвидобальдо II, которые курировали ход работ после смерти Юлия II.

Неприятности начались с самого начала: мрамор был доставлен в Рим в таком количестве, что, по словам Вазари, им оказалась завалена половина площади Святого Петра; за доставку одной из партий Микеланджело пришлось заплатить из своего кармана, а когда он пошел к папе с просьбой возместить убытки, его, ссылаясь на занятость папы, просто отказались впустить. Биографы скульптора сообщают, что разгневанный Микеланджело заявил: «Передайте nane, что впредь, если он захочет видеть меня, то может искатьменя, где ему угодно» и той же ночью уехал во Флоренцию, где оставался на протяжении 


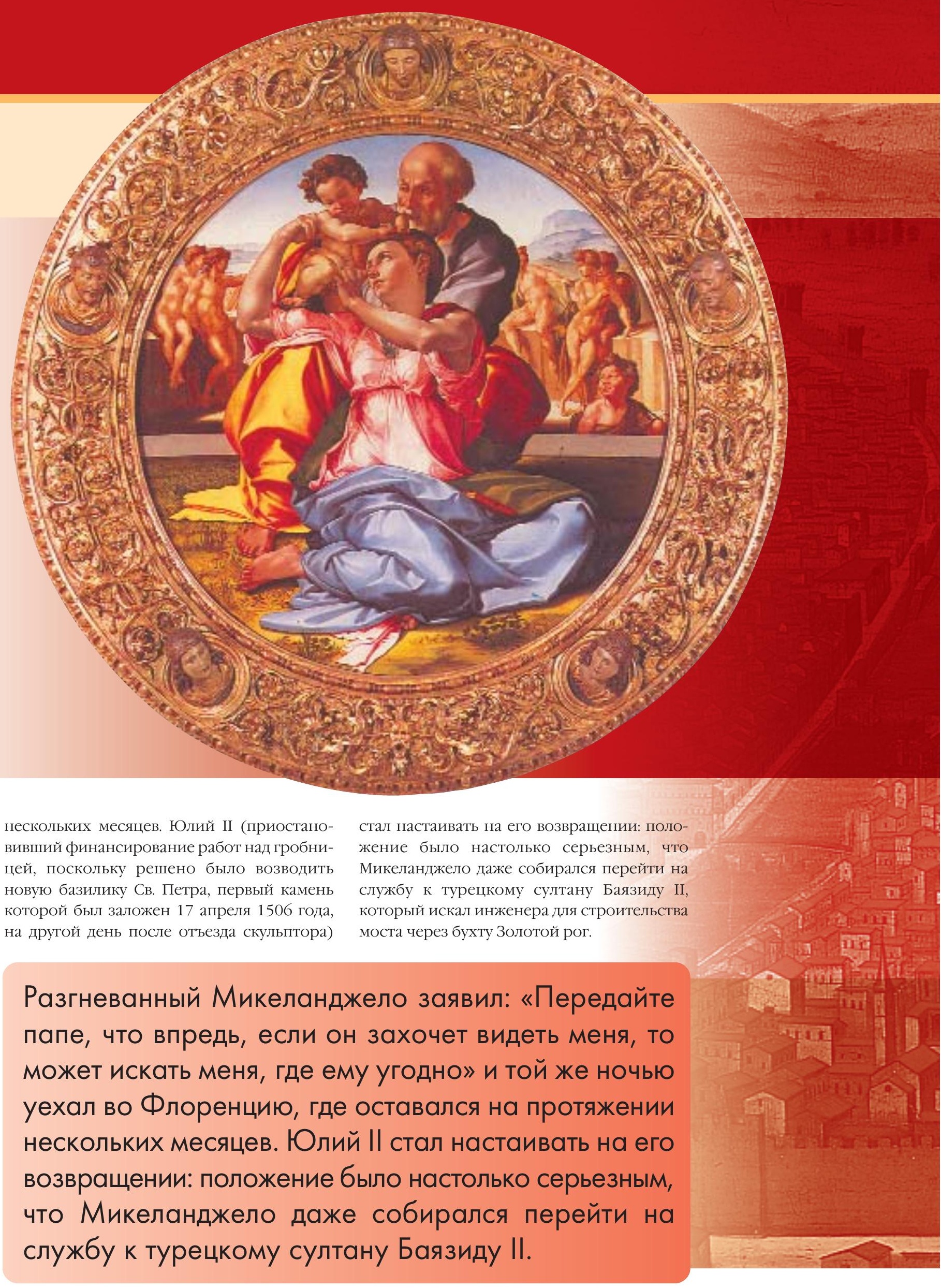




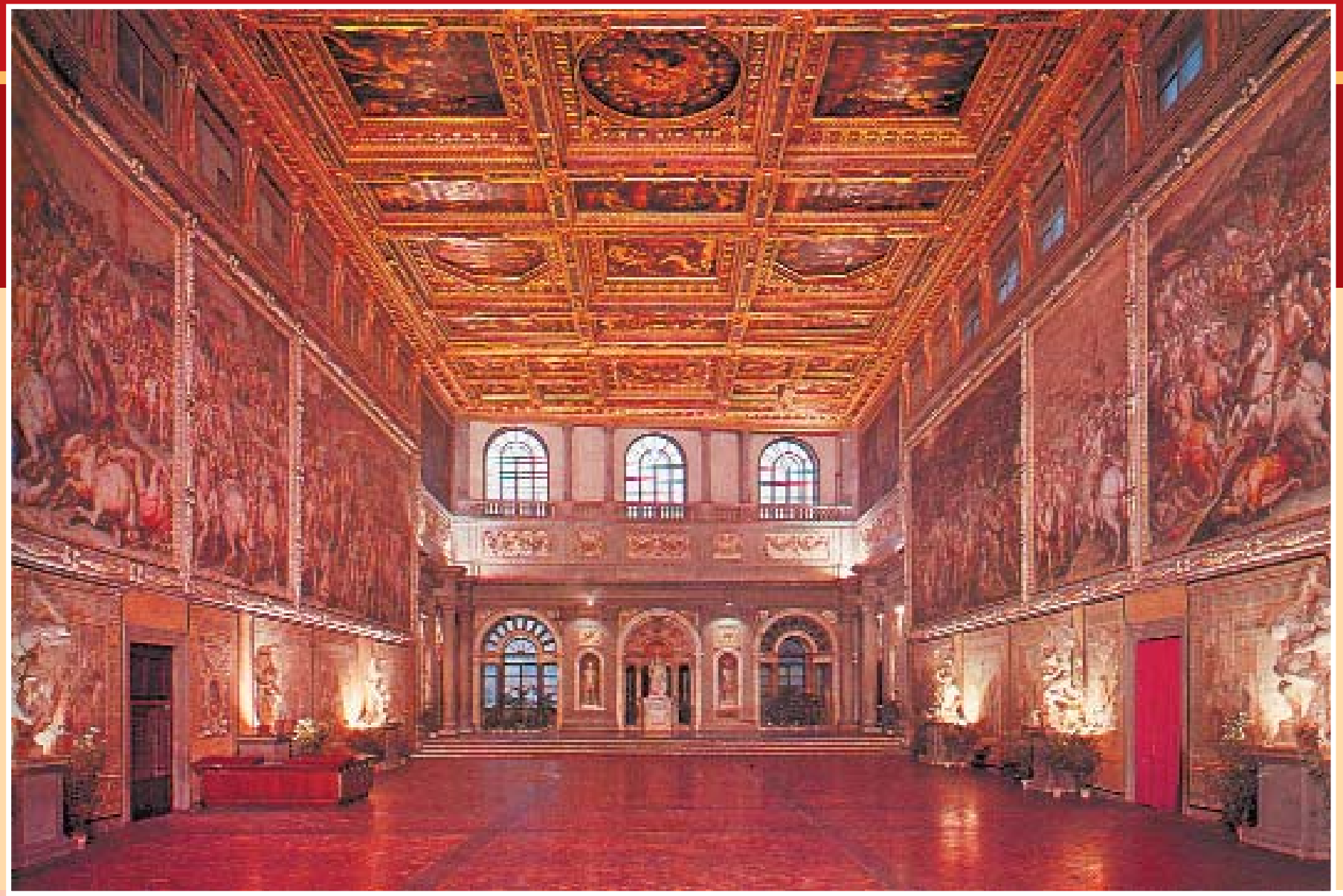

Много позже, в конце 1523 года, в одном из писем к своему другу Джованни Франческо Фаттуччи Микеланджело так вспоминал об обстоятельствах конфликта с папой: «...Когда я находился в Риме при названном папе Юлии и когда он заказал мне свою гробнииу, на которую уходило на тысячу дукатов одного мрамора, он приказал мне их уплатить и послал меня за мрамором в Каррару, где я пробыл почти восемь месячев, отдавал в от- теску и перевез почти все глыбы на площадь Санто Пьетро, часть же их осталась в Рипа.Далее, закончив выплаты портовых пошлин и истратив все деньги, полученные за названную работу, я обставил дом, которым владел на площади Санто Пъетро, кроватями и всяким скарбом на свои средства. В надежде на гробнииу я выписал из Флорениии для работы подмастеръев, некоторые из них до сих пор живы, и заплатил им деньги вперед из своих
И тогда, и в дальнейшем, Микеланджело преувеличивал свои финансовые трудности - на самом деле он положил часть денег, полученных от папы, в банк и впоследствии купил на них дом и землю. В оправдание подобной расчетливости, можно заметить, что с юных лет на его иждивении находилась в буквальном смысле вся многочисленная семья. средств. В это время папа Юлий переменил свое намерение и не хотел продолжать гробницы. Я же, не зная этого и отправивиись к нему за денъгами, был изгнан из его покоев. Из-за этой обиды я тотчас же покинул Рим.И то, что я имел в доме, пошло прахом, а названные глыбы, которые были мною привезены, простояли на площади Санто Пьетро до избрания папыЛъва.Истойи сдругой стороны все складывалось как нельзя хуже. В числе прочего, что я могу доказать, Агостино Киджи похитил у меня в Рипа две глыбы по четыре с половиной локтя каждая, которые стоили мне больше пятидесяти дукатов золотол; эти деньги можно было бы получить обратно потому, что имеются свидетели. Однако возврашаюов к мрамору. С того времени, как я за ним ездил и оставался в Карраре, и вплоть до того, как меня выгнали из двориа, прошло больше года. За это время я ни разу не получал, а вложил несколько десятков дукатов. Далее, первый раз, как папа Юлий побывал в Болонье, я вынужден был туда отправитьса и с веревкой на шее 
Слева:

Зал Пятисот в палаццо Веккьо. Современный вид.

Cправа:

Пьеро Содерини. Гравюра XVI в.

Внизу:

Битва при Кашине (с картона Микеланджело). Худ. Бастиано да Сангалло. Холкхэм-холл, Норфолк.

просить промения. После чего он поручил мне сделать из бронзы его фигуру, которая, сидя, была в высоту около шести локтей. Когда он спросил, сколько она обойдется, я ответил, что собираюось отливать ее за тысячу дукатов, но что это не мое искусство и что я не хочу себя обязывать. Он мне ответил: «Иди, работай и отливай ее столько раз, сколько понадобится, а мы заплатии тебе столько, что ты будешь доволен». Словом, ее отливали дважды, и за два года, что я там пробыл, я, как оказалось, разбогател на четыре с половиной дуката. С тех пор я ничего больие не nолучал». Однако действительность была более прозаичной: как выяснил итальянский исследователь Антонио Форчеллино, и тогда, и в дальнейшем, Микеланджело преувеличивал свои финансовые трудности - на самом деле он положил часть денег, полученных от папы, в банк и впоследствии купил на них дом и землю. В оправдание подобной (казалось бы, нехарактерной для творческого человека) расчетливости, можно заметить, что с юных лет на его иждивении находилась в буквальном смысле вся многочисленная семья. Лодовико Буонарроти, отличавшийся непрак-

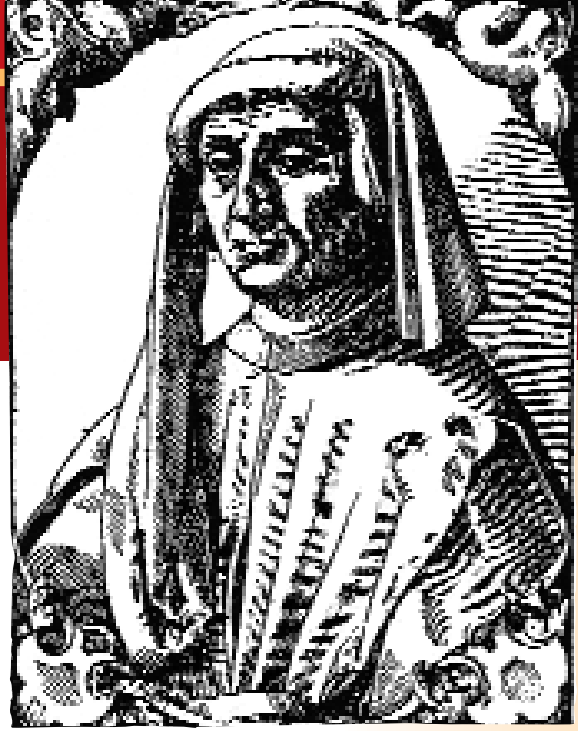

тичностью и неразборчивостью в денежных делах, всегда был откровенно равнодушен к художественной деятельности своего одаренного сына, но живо интересовался деньгами, которые тот зарабатывал и которыми щедро снабжал его и братьев. ${ }^{12}$ При всяком удобном

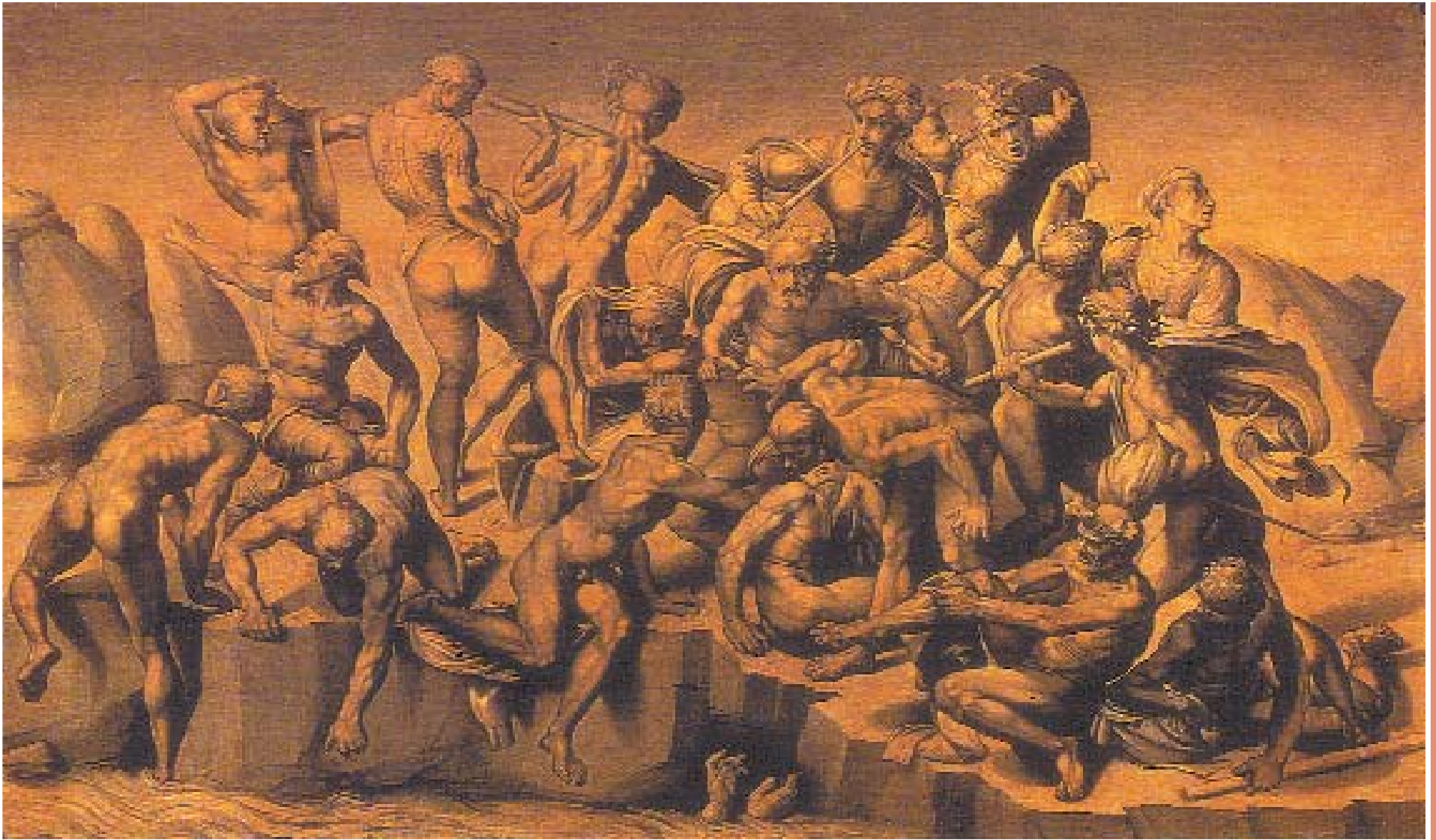

2 У Лодовико кроме Микеланджело, его второго ребенка, было четверо сыновей: Лионардо (1473-1510 г2.), Буонаррото (1477-1528 г2.), Джовансимоне (1479-1548 г2.) и Джисмондо (1481-1555 г2.) Поскольку Лионардо стал в 1491 г. монахом доминиканского ордена, Микеланджело считался в семье стариим из братьев. Это заставляло его все время чувствовать за них моральную ответственностью. Братья же беззастенчиво эксплуатировали его чувство семейного долга. - Прим.ред. 


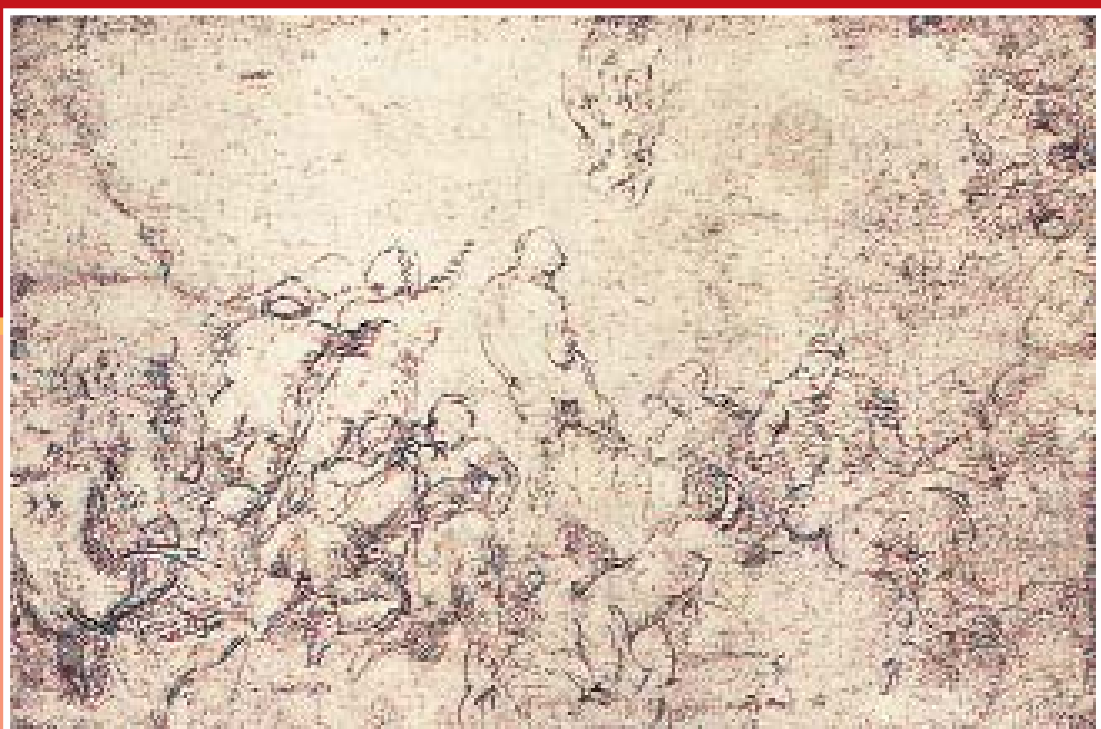

случае он использовал растущее общественное положение знаменитого сына. Так, например, в 1512 году свое прошение на имя Джулиано Медичи он подписывает «одовико Буонарроти, отеи, Микельаньоло скульптора».

Конфликт Микеланджело с Юлием II породил оживленную дипломатическую переписку на высшем уровне: посредниками между ними выступали Пьеро Содерини, его брат епископ Вольтерры кардинал Франческо Содерини, папский архитектор Джулиано да Сангалло, в письме к которому 2 мая 1506 года Микеланджело мотивировал свое поведение следующим образом: «Что касаетса моего отъезда, то, по правде говоря, я сльшал, как папа, разговаривая в страстную субботу за столом с одним ювелиром и с иеремонийлеистером, сказал, что он не хочет больше тратить ни гроша ни на мелкие, ни на крупные камни, чему я весыма подивился. Однако незадолго до моего отвезда я попросил у него часть того, что мне причиталось, для продолжения работы. Его Святейшество мне ответил, чтобы я вернулся в понедельник. И я возврашался туда и в понедельник, и во вторник, и в среду, и в четверг, как Его Святейшество и мог видеть. Наконеи, в пятнииу утром мне приказали уйти, попросту выгнали;

${ }^{13}$ По утверждению Кондиви, это был кардинал Содерини, но Вазари пишет, что он не присутствовал при этой встрече, так как был болен. и тот, кто мне приказал уйти, сказал, что он меня знает, но что это ему было поручено. Посему я, после того как в названную суб боту услыхал названные слова и увидел потом их действие, впал в великое отчаяние. Но не только это было исключительной причи ной моего отвезда; было также и другое, о чем я не хочу писать. Достаточно сказать, что это заставило меня задуматься, не будет ли, если я останусь в Риме, моя гробница воздвигнута раньие, чем гробница папы...». Однако и два месяца спустя Юлий II продолжал демонстрировать перед членами Синьории неведение относительно причин вызывающего поведения Микеланджело.

Наконец, Пьеро Содерини все же убедил Микеланджело отправиться на встречу с папой, состоявшуюся 29 ноября 1506 года в Болонье, которая тогда была оккупирована папскими войсками. По рассказам Вазари, Микеланджело тут же был вызван к Юлию II, который, «взглянул на него искоса, будто гневно, и сказал ему: "Вместо того чтобы тебе к нам приитти, ты ждал, когда
Композиционный эскиз Микеланджело к картону «Битва при Кашине».

Около 1504 г.

Галерея Уффици, Флоренция.

Одно время этот эскиз сиитался копией, выполненной с картона Микеланджело художником-манъеристом А. Аллори. мы придем к тебе?" - желая сказать әтим, что Болонья ближе к Флорениии, чем Рим. Воздев руки, Микеланджело громким голосом смиренно попросилу него прощения за то, что поступил он так, вспьлив, не будучи в состоянии перенести, что его попросту выгнали вон, $u$, признавая свою вину, он еше раз попросил прощения. Епископ, предс-

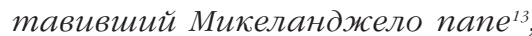
в его оправдание говорил Его Святейшеству, что люди подобного рода невежественны и помимо своего искусства ни в чем другом ничего не смыслат, и чтобы поэтому он соблаговолил его простить. Папа рассердился и дубинкой, которую он держал, ударил епископа с такими словами: «Это ты невежда, что говоришь о нем гнусности, каких мы ему не говорим». После чего привратники вытолкали епископа вон, папа же, излив на него свой гнев, благословил Микеланджело, которого дарами и посулами задержали в Болонъе, пока Его Святейшество не заказал ему свою бронзовую статую». Вазари добавляет, что когда Юлий II пришел взглянуть на готовую модель, скульптор еще не знал, «мто вложить ей в левую руку, а так как правая была гордо поднята, папа спросил, что же он делает: благословляет или проклинает? Микеланджело ответил, что он увещевает болонский народ вести себя благоразумно. Когда же он спросил, как полагает Его Святейшество, не вложить ли
Работа над статуей была для Микеланджело трудной и тягостной. Он был обижен, к тому же не привык работать в бронзе, поэтому пришлось нанимать мастеров для отливки. Наконец, 18 марта 1508 г. бронзовая статуя папы была установлена в церкви Сан Петронио. 
ему в левую руку книгу, тот ответил: «Даймне в руку меч - ячеловек неученыци». Работа над статуей была для Микеланджело трудной и тягостной. Он был обижен, к тому же не привык работать в бронзе, поэтому пришлось нанимать мастеров для отливки. Наконец, 18 марта 1508 года бронзовая статуя папы была установлена в церкви Сан Петронио, но в декабре 1511 года во время восстания, сопровождавшего возвращение в Болонью изгнанного правителя Аннибале Бентивольо, статуя была переплавлена в пушку.

В марте 1508 года Микеланджело возвращается во Флоренцию, где ненадолго обретает «мир $u$ nокой». Еще во время тяжбы с Юлием II он начинал работать над двенадцатью статуями апостолов, заказанных для украшения флорентийского собора еще в 1503 году консулами цеха шерстянщиков. Он стал уже высекать статую Св. Матфея, когда разразившийся скандал потребовал его возвращения в Рим.

По мнению В.Н. Лазарева, незаконченная статуя апостола Матфея является «поистине трагическил финалом первого периода творчества» Микеланджело, и во многом предвосхищает зрелый и поздний стиль мастера: «ля раннего периода это самая драматическая по замыслу вешь. Возможно, что Микеланджело вложил в нее горечь разочарования, порожденного «трагедией гробницы». Образ Матфея по общему своему духу близок позднейиим образам "рабов", предусмотренных уже в первом варианте гробницы Юлия. Не имея возможности осуществить многое из того, что он собирался воплотить в фигурах «рабов». [...] Фигура как бы стремится высвободиться из камня, камень же держит ее в своих жестких объятиях. Отсюда рождается совсем особый трагизм образа, подчеркнутый незаконченностью статуи.

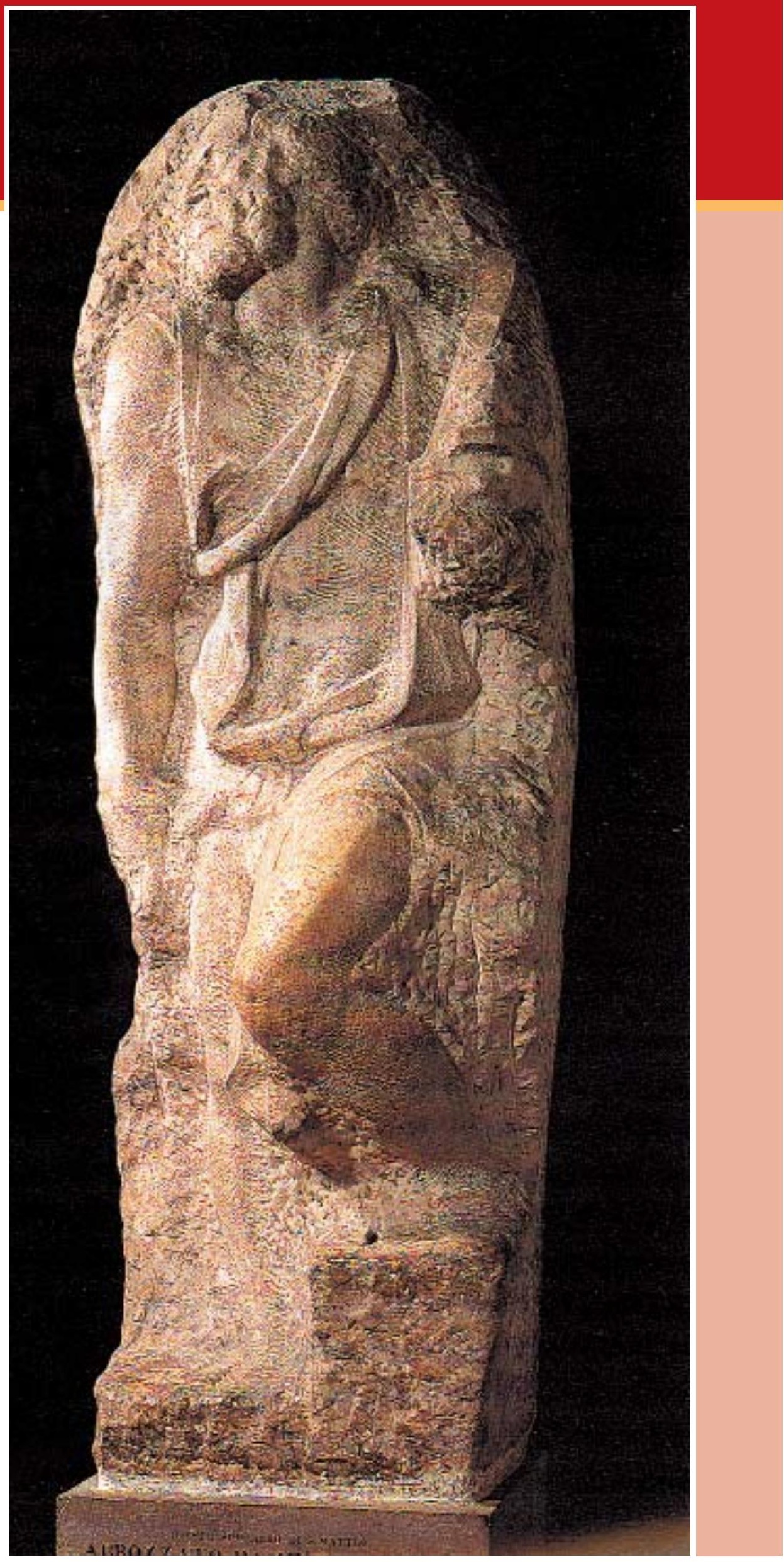

